\title{
Fungal Toxins and Host Immune Responses
}

\author{
Rhys Brown, Emily Priest, Julian R. Naglik and Jonathan P. Richardson* \\ Centre for Host-Microbiome Interactions, Faculty of Dentistry, Oral \& Craniofacial Sciences, King's College London, London, \\ United Kingdom
}

Fungi are ubiquitous organisms that thrive in diverse natural environments including soils, plants, animals, and the human body. In response to warmth, humidity, and moisture, certain fungi which grow on crops and harvested foodstuffs can produce mycotoxins; secondary metabolites which when ingested have a deleterious impact on health. Ongoing research indicates that some mycotoxins and, more recently, peptide toxins are also produced during active fungal infection in humans and experimental models. A combination of innate and adaptive immune recognition allows the host to eliminate invading pathogens from the body. However, imbalances in immune homeostasis often facilitate microbial infection. Despite the wide-ranging effects of

OPEN ACCESS

Edited by:

Ludovic Tailleux,

Institut Pasteur, France

Reviewed by:

Philippe Guerre,

Ecole Nationale Vétérinaire

de Toulouse, France

Eva M. Galvez,

Institute of Carbochemistry (CSIC),

Spain

*Correspondence:

Jonathan P. Richardson

jonathan.richardson@kcl.ac.uk

Specialty section:

This article was submitted to

Microbial Immunology,

a section of the journal

Frontiers in Microbiology

Received: 18 December 2020

Accepted: 08 March 2021

Published: 13 April 2021

Citation:

Brown R, Priest E, Naglik JR and Richardson JP (2021) Fungal Toxins

and Host Immune Responses.

Front. Microbiol. 12:643639.

doi: 10.3389/fmicb.2021.643639 fungal toxins on health, our understanding of toxin-mediated modulation of immune responses is incomplete. This review will explore the current understanding of fungal toxins and how they contribute to the modulation of host immunity.

Keywords: fungal toxins, mycotoxins, candidalysin, immunity, toxins

\section{INTRODUCTION}

Mycotoxins are natural secondary metabolites produced by fungi which grow on a variety of agricultural products including cereals, grains, nuts, spices, apples, dried fruits, and coffee beans (Ukwuru et al., 2017). It is estimated that $20-25 \%$ of food crops worldwide contain mycotoxin contamination (Eskola et al., 2020) while mycotoxins and mycotoxin-producing fungi are frequently isolated from construction materials and air samples from water-damaged buildings (Tuomi et al., 2000).

The majority of mycotoxins are synthesised by enzymes present in biosynthetic gene clusters whose first enzyme is a polyketide synthase or a non-ribosomal peptide synthetase (or a mixture of both), with the exception of candidalysin and mucoricin [peptide and protein toxins encoded by ECE1 and RLT1 genes, respectively (Gallo et al., 2013; Moyes et al., 2016; Soliman et al., 2021)]. The gut is typically the first point of contact between ingested mycotoxins and the host. The gastrointestinal mucosa (GIM) is a single layer of epithelial cells which are physically connected to one another by desmosomes, tight junctions and adherens junctions. The GIM is colonised by a diverse range of bacteria, archaea, and eukarya which play a critical role in the maintenance of general health. While the protective barrier of the GIM serves to restrict the movement of microbes and toxic substances from the gastrointestinal lumen into the systemic compartment, compromised barrier function and alterations in the composition of the resident microbiota may predispose to disease. The deleterious impact of mycotoxin-induced alterations on intestinal barrier function are reviewed in Gao et al. (2020a). 
Mycotoxins can influence the gastrointestinal microbiota directly through antimicrobial activity and through secondary mechanisms involving the release of antimicrobial compounds from mycotoxin-damaged host cells. Numerous studies have investigated the impact of mycotoxins on host microbiota in vivo (Guerre, 2020). Conversely, the microbiota can also influence the bioavailability of ingested mycotoxins and their associated metabolites. Mycotoxins can be detoxified through biotransformation ( $\mathrm{Li}$ et al., 2020) and physically sequestered by direct adsorption onto microbial cell walls which impairs their absorption across the gut. However, it is also worth noting that the process of biotransformation may also generate compounds that are potentially toxic. One notable example of this phenomenon is the bioactivation of "masked" mycotoxins. Plants protect themselves from mycotoxins in a process which typically involves the conversion of mycotoxins into compounds with reduced toxicity (referred to as "masked" mycotoxins) which remain stored in plant tissue. Should plant material containing masked mycotoxins be ingested, host processes and/or the biological activity of the resident microbiota can liberate functional mycotoxins (and related metabolites) which may have detrimental consequences (Berthiller et al., 2013; Gratz, 2017; Gratz et al., 2017).

The predominant routes of exposure to mycotoxins are ingestion and inhalation. However, recent research indicates that some mycotoxins and peptide/protein toxins are associated with fungal infection and contribute to pathogenicity. Fungal diseases are a major cause of morbidity and mortality in the global population and account for an estimated 1.5 million deaths per year (Brown et al., 2012). Compromised immunity and iatrogenic procedures such as gastrointestinal surgery and immunosuppressive therapy are risk factors for the development of life-threatening systemic infections. The saprophytic mould Aspergillus fumigatus produces gliotoxin which is detectable in the lungs of patients with invasive aspergillosis (IA; Lewis et al., 2005) while the production of candidalysin by Candida albicans contributes to mucosal and systemic disease in a range of experimental models (Naglik et al., 2019).

Innate and adaptive immunity are critical for the control and elimination of infecting microbes. The mucosal barriers of the body, together with immune cells, serve to protect underlying tissues from pathogenic insult and play an active role in microbial recognition and defence. Mucosal surfaces activate and orchestrate cellular responses to microbial infection through the production of cytokines and alarmins which drive the recruitment of specialised innate and adaptive immune cells including macrophages, neutrophils, dendritic cells and $\mathrm{T}$ cells to combat invading microbes. However, the majority of mycotoxins have a deleterious effect on the structural integrity of mucosal barriers and are capable of suppressing cellular immunity. Accordingly, toxin-mediated alterations in innate and adaptive host defences may increase susceptibility to infection by pathobionts present in the resident microbiota. This review will explore the impact of mycotoxins, peptide, and protein toxins on the modulation of host immune defence.

\section{GLIOTOXIN}

Gliotoxin ((3R,6S,10aR)-6-hydroxy-3-(hydroxymethyl)-2-methyl -2,3,6,10-tetrahydro-5aH-3,10a-epidithiopyrazino[1,2-a]indole -1,4-dione: Figure 1A) is a member of the epipolythiodioxopiperazine (ETP) class of toxins. Numerous studies have suggested that the toxicity of ETP toxins and gliotoxin in particular may be, in part, underpinned by redox cycling of the disulphide bridge which can generate damaging reactive oxygen species (ROS) and drive the formation of mixed disulphide bonds with host proteins (Chai and Waring, 2000). Although gliotoxin was first characterised in the fungal genus Gliocladium (Weindling and Emerson, 1936; Weindling, 1941), the fungus most closely associated with gliotoxin is A. fumigatus, which causes a range of life-threatening respiratory and systemic infections in patients with compromised immunity. Gliotoxin is detectable in the serum of patients with IA and in the lungs and serum of mice with experimentally induced IA (Lewis et al., 2005) suggesting an association with active infection.

\section{Epithelial Cells and Gliotoxin}

The germination of A. fumigatus conidia and subsequent invasion into the respiratory epithelium is a critical step which promotes infection. Gliotoxin promotes cytoskeletal remodelling in human alveolar epithelial cells in vitro which facilitates the internalisation of A. fumigatus conidia (Jia et al., 2014; Zhang et al., 2019). Fungal burdens present in the lung tissue of immunosuppressed mice infected with an A. fumigatus gliP $\Delta$ mutant unable to produce gliotoxin were significantly reduced compared with wild-type fungus, and the invasive capacity of the gliP $\Delta$ mutant was partially restored following the addition of exogenous gliotoxin which correlated with increased mortality (Jia et al., 2014; Zhang et al., 2019). Murine embryonic fibroblasts exposed to $1 \mu \mathrm{M}$ gliotoxin in vitro undergo apoptosis in a Bcl-2 homologous antagonist/killer (Bak) dependent manner (Pardo et al., 2006), while immunosuppressed $\mathrm{Bak}^{-/-}$mice that received an intranasal inoculation of gliotoxin-producing A. fumigatus were more resistant to infection compared with wild-type controls, highlighting the role of Bak as critical factor involved in gliotoxin-mediated cell death (Pardo et al., 2006). The application of gliotoxin or exhausted culture medium from wildtype A. fumigatus but not a gliotoxin-defective mutant induces apoptosis in human bronchial epithelial cells, and in murine fibroblasts and alveolar epithelial cells in a c-Jun N-terminal kinase (JNK) pathway-dependent manner (Geissler et al., 2013).

\section{Macrophages and Gliotoxin}

Gliotoxin induces apoptosis and cytoskeletal changes that affect macrophage function. Macrophages exposed to $0.3-3 \mu \mathrm{M}$ gliotoxin in vitro undergo DNA fragmentation and apoptosis within $5 \mathrm{~h}$ (Waring et al., 1988; Suen et al., 2001). The phagocytic ability of macrophages is significantly diminished through the specific targeting of phosphoinositides. Phosphatidylinositol 3,4,5-trisphosphate (PtdIns $(3,4,5) \mathrm{P} 3)$ is an important component involved in cytoskeletal remodelling in macrophages during phagocytosis (Levin et al., 2015). Gliotoxin (1.53 $\mu \mathrm{M})$ induces the dissociation of PtdIns $(3,4,5) \mathrm{P} 3$ from primary human and murine 
<smiles>CN1C(=O)C23CC4=CC=C[C@H](O)[C@]4(C)N2C(=O)[C@]1(CO)S3</smiles>

A<smiles>COc1cc2c(c3oc(=O)c4c(c13)CCC4=O)CO2</smiles>

B<smiles>CCCC[C@H](C)[C@H](OC(=O)C[C@H](CC(=O)O)C(=O)O)[C@H](C[C@@H](C)C[C@@H](O)CCCC[C@H](O)C[C@H](O)[C@H](C)N)OC(=O)C[C@@H](O)C(=O)O</smiles><smiles>CC(=O)OC[C@]12C[C@@H](OC(=O)CC(C)C)C(C)=C[C@H]1O[C@H]1[C@@H](O)[C@H](OC(C)=O)[C@@]2(C)[C@H]1O</smiles>

E<smiles>O=C1C=C2C(=CCOC2O)O1</smiles>

G

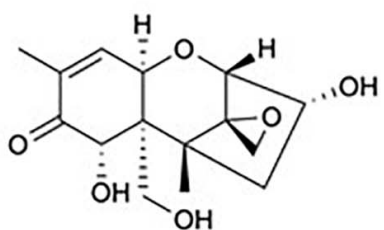

F<smiles>C[C@H]1CCCC(=O)CCC/C=C/c2cc(O)cc(O)c2C(=O)O1</smiles>

H

FIGURE 1 | Chemical structure of common mycotoxins. (A) Gliotoxin $\left(\mathrm{C}_{13} \mathrm{H}_{14} \mathrm{~N}_{2} \mathrm{O}_{4} \mathrm{~S}_{2}\right)$ is a member of the epipolythiodioxopiperazine family of mycotoxins and is produced by Aspergillus fumigatus. (B) Aflatoxin $\mathrm{B} 1\left(\mathrm{C}_{17} \mathrm{H}_{12} \mathrm{O}_{6}\right)$ produced by $A$. flavus and A. parasiticus. (C) Ochratoxin $\mathrm{A}\left(\mathrm{C}_{20} \mathrm{H}_{18} \mathrm{ClNO}_{6}\right)$ is a phenylalanine derivative produced by several species of the genera Aspergillus and Penicillium. (D) Fumonisin $B 1\left(\mathrm{C}_{34} \mathrm{H}_{59} \mathrm{NO}_{15}\right)$ is characterised by diester and triol functional groups and is produced by species of the genus Fusarium. The trichothecenes family include: (E) The type A trichothecene $\mathrm{T}-2\left(\mathrm{C}_{24} \mathrm{H}_{34} \mathrm{O}_{9}\right)$ and $\mathbf{( F )}$ The type B trichothecene Deoxynivalenol $\left(\mathrm{C}_{15} \mathrm{H}_{20} \mathrm{O}_{6}\right)$. T-2 and Deoxynivalenol are produced by numerous genera of fungi including Fusarium, Stachybotrys, and Trichoderma. (G) Patulin $\left(\mathrm{C}_{7} \mathrm{H}_{6} \mathrm{O}_{4}\right)$ is produced by species of the genera Aspergillus and Penicillium. (H) Zearalenone $\left(\mathrm{C}_{18} \mathrm{H}_{22} \mathrm{O}_{5}\right)$ is produced by species of the genera Fusarium and Gibberella.

RAW 264.7 macrophage plasma membranes which promoted cytoskeletal reorganisation, inhibition of lamellipodia formation, and phagocytosis of zymosan (Schlam et al., 2016).
Cytokines are key molecules in the coordination of immune responses and gliotoxin has been shown to affect cytokine expression and release from macrophages. Gliotoxin $(0-4.6 \mu \mathrm{M})$ 
modulates the secretion of interleukin (IL)-6, IL-10, and tumour necrosis factor (TNF)- $\alpha$ from lipopolysaccharide (LPS)stimulated human MM6 monocytes in vitro (Johannessen et al., 2005) while concentrations as low as $107 \mathrm{nM}$ induce apoptosis (Stanzani et al., 2005). Further evidence for the inhibition of cytokine responses is provided by studies in which LPSstimulated rat macrophages treated with $0.3-3 \mu \mathrm{M}$ gliotoxin exhibited a reduction in the level of TNF- $\alpha$ secretion in vitro (Fitzpatrick et al., 2000).

Recent research has highlighted a critical role for macrophages in toxin surveillance and the maintenance of barrier function in the distal colon. Murine colonocytes are protected from the toxicity of gliotoxin, T-2 toxin and candidalysin by a population of CD11 $c^{\text {high }}$ subepithelial macrophages which form specialised "balloon-like" protrusions (BLPs) in response to local fungi, and use them to interact with the distal colonic epithelium where they limit the absorption of toxic materials (Chikina et al., 2020). Strikingly, in mice that are depleted for these macrophages, the distal colonic epithelium continues to absorb toxin-containing fluids and undergoes apoptosis concomitant with a loss of barrier integrity. These observations suggest that the BLPs enable colonic epithelial cells to differentiate between harmless and harmful substances and identify CD11 $c^{\text {high }}$ subepithelial macrophages as central mediators of colonic barrier function and local responses to fungal toxins in vivo (Chikina et al., 2020).

\section{Neutrophils and Gliotoxin}

Neutrophils play a major role in the control of fungal infection. Human neutrophils treated with concentrations (92-306 nM) of gliotoxin found in the blood of patients with IA were unable to phagocytose zymosan or serum-opsonised zymosan and exhibited cytoskeletal re-organisation (Coméra et al., 2007). Similarly, isolated polymorphonuclear leukocytes exposed to $107 \mathrm{nM}$ gliotoxin exhibited reduced production of ROS within 30 min (Orciuolo et al., 2007).

The production of neutrophil extracellular traps (NETs) occurs in response to the presence of invading fungi that are too large to be phagocytosed, and the NADPH oxidative burst promotes the formation of NETs in an in vivo model of pulmonary aspergillosis (Almyroudis et al., 2013, Röhm et al., 2014). Gliotoxin has been shown to inhibit assembly of the NADPH oxidase in human neutrophils (Tsunawaki et al., 2004).

In vivo, immunosuppressed neutropenic mice infected with an A. fumigatus $\Delta$ gliZ mutant unable to produce gliotoxin exhibited a non-significant improvement in survival after seven days when compared with wild-type controls (Bok et al., 2006). Additionally, a significant increase in the survival of neutropenic mice was observed following disruption of the A. fumigatus transcriptional regulator $L a e A$, which was associated with decreased production of gliotoxin and an increased susceptibility to phagocytosis (Bok et al., 2005). No difference in survival was observed between groups of neutropenic mice infected with wild-type A. fumigatus conidia or a $\Delta$ gliP mutant unable to produce gliotoxin (Kupfahl et al., 2006). In contrast, immunosuppressed, non-neutropenic mice infected with the same strains exhibited significantly improved survival (Sugui et al., 2007). Indeed, a $\Delta$ gliP mutant unable to produce gliotoxin exhibited attenuated virulence in non-neutropenic murine models of invasive pulmonary aspergillosis, but exhibited normal virulence in models rendered neutropenic (Spikes et al., 2008). These observations suggest that non-neutropenic mice are more susceptible to the effects of gliotoxin in a model of IA and highlight neutrophils as a primary target of the toxin.

\section{Dendritic Cells and Gliotoxin}

Dendritic cells are capable of innate recognition of pathogens and also present antigens to naive $\mathrm{T}$ cells during adaptive immunity. Gliotoxin $(0.1 \mu \mathrm{M})$ induced caspase- 3 activation and apoptosis in $\mathrm{CD} 3^{+}$monocyte-derived dendritic cells while concentrations between 0.15 and $1.5 \mu \mathrm{M}$ inhibited human $\mathrm{T}$ cell function in vitro (Stanzani et al., 2005).

\section{Nuclear Factor kappa-B and Gliotoxin}

Nuclear factor kappa-B (NF- $\mathrm{B})$ signalling plays a role in numerous aspects of innate immunity including immune cell survival and the production of pro-inflammatory M1 macrophages (Ward et al., 1999; Cowburn et al., 2004; François et al., 2005; Wang et al., 2014). Multiple studies have demonstrated that gliotoxin targets NF-кB signalling to promote immune suppression.

Treatment of Jurkat T cells with $306 \mathrm{nM}$ gliotoxin abolished NF- $\kappa \mathrm{B}$ signalling by preventing the degradation of the regulatory

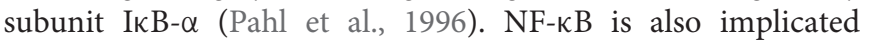
in gliotoxin-induced apoptosis of eosinophils. Eosinophils that received TNF- $\alpha$ and $306 \mathrm{nM}$ gliotoxin stabilised IкB- $\alpha$, resulting in NF- $\kappa$ B inhibition, a significant increase in apoptosis and a decrease in the production of IL-8 (Fujihara et al., 2002). The multiple impacts of gliotoxin on host immune responses are summarised in Figure 2.

\section{AFLATOXINS}

Aflatoxins are potent, coumarin ring-containing carcinogens derived from polyketides. There are least 18 different members comprised of aflatoxins and their derivatives (Benkerroum, $2020 \mathrm{~b}$ ) but the most widely studied of these are B1, B2, G1, and G2. Aflatoxin $\mathrm{B}_{1}((6 \mathrm{a} R, 9 \mathrm{a} S)-2,3,6 \mathrm{a}, 9 \mathrm{a}$-tetrahydro-4-methoxy$1 H, 11 H$-cyclopenta[c]furo[ $\left.3^{\prime}, 2^{\prime}: 4,5\right]$ furo[2,3-h] [1] benzopyran-

1,11-dione: Figure 1B) was first isolated in 1961 and takes its name from Aspergillus flavus (Blount, 1961; Schroeder and Boller, 1973; Saito et al., 1989; Geiser et al., 2000). More recent research has demonstrated that aflatoxins are produced by numerous Aspergillus species (Goto et al., 1996; Geiser et al., 2000; Klich et al., 2000; Peterson et al., 2001).

Aflatoxin $B_{1}$ is widely considered to be the most toxic of the aflatoxins. Aflatoxin $\mathrm{B}_{1}$ and $\mathrm{B}_{2}$ are produced by $A$. flavus and are thus often found as co-contaminants. The toxicity of aflatoxin $B_{1}$ is caused predominantly through the production of the highly unstable intermediate metabolite aflatoxin $\mathrm{B}_{1}$ exo8,9 epoxide (AFBO). AFBO induces cytotoxicity by reacting with host macromolecules including nucleic acids, proteins, and phospholipids (Benkerroum, 2020a). Intriguingly, AFBO is not an intermediate derived from the metabolism of aflatoxin $B_{2}$, 


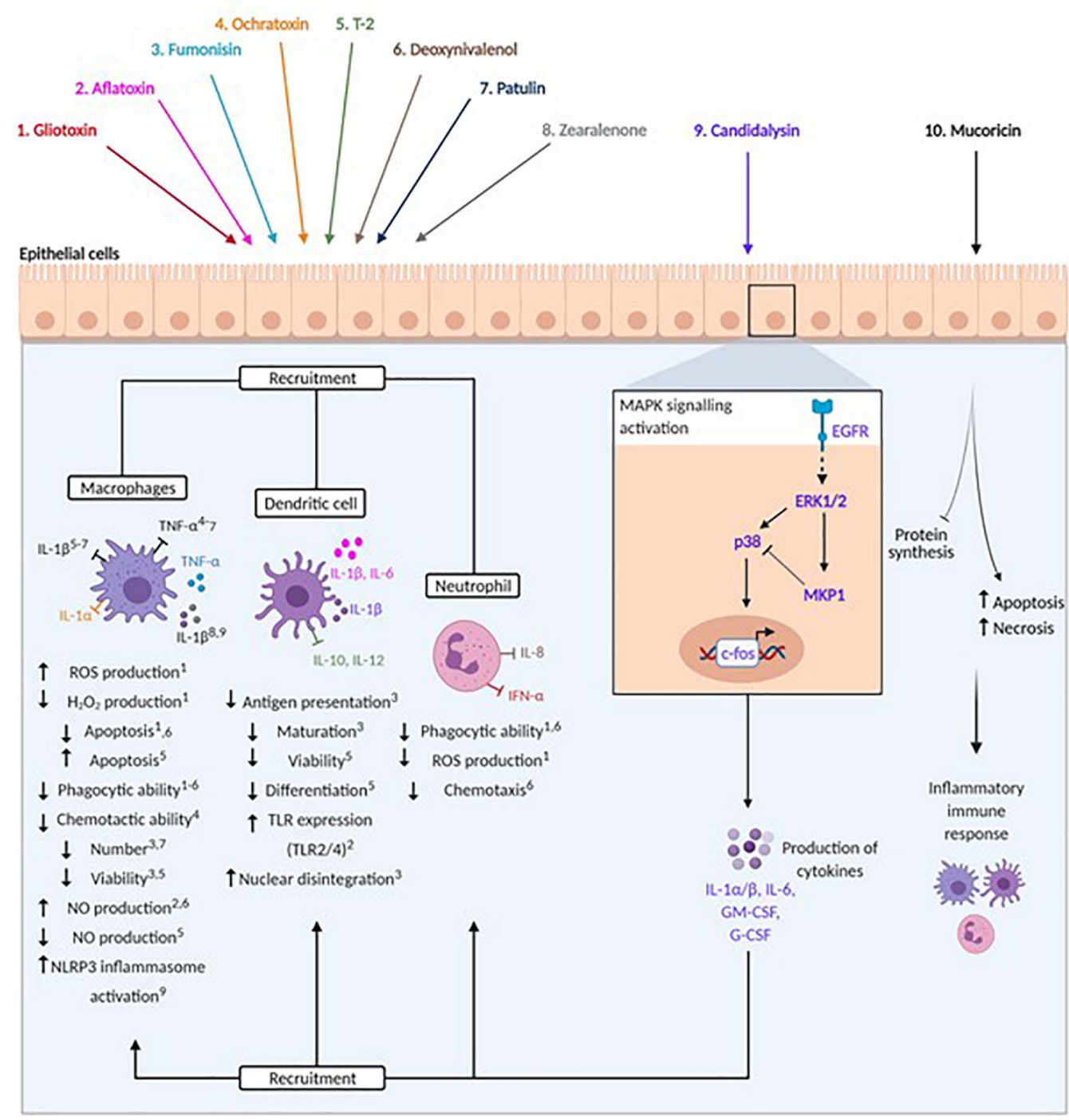

FIGURE 2 | Modulation of host immunity by mycotoxins, peptide and protein toxins. Fungal toxins are represented by colours: 1. Gliotoxin (red), 2. Aflatoxin (pink), 3. Fumonisin (light blue), 4. Ochratoxin (orange), 5. T-2 (green), 6. Deoxynivalenol (brown), 7. Patulin (dark blue), 8. Zearalenone (grey), 9. Candidalysin (purple), 10. Mucoricin (black). Arrows beneath immune cells denote promotion or reduction of indicated processes. Numbers in superscript identify processes affected by specific toxins. Pro- and anti-inflammatory cytokines are indicated by spheres and arrows (stimulation) and blunted arrows (inhibition).

hinting at an explanation for the reduced toxicity of aflatoxin $\mathrm{B}_{2}$ compared to $\mathrm{B}_{1}$ (Benkerroum, 2020a).

Aflatoxins cause a wide range of toxicoses and predominantly target the liver, resulting in cirrhosis and hepatocellular carcinoma (Newberne and Butler, 1969; Shank et al., 1972; Peers, 1973; Mekuria et al., 2020). Indeed, the mean concentration of free aflatoxin $B_{1}$ in the serum of patients with hepatocellular carcinoma was $0.2 \mathrm{nM}$ compared with $0.06 \mathrm{nM}$ in healthy controls (Aydin et al., 2015; Ferri et al., 2017). The presence of aflatoxin-albumin adducts is an often-used biomarker of exposure and adduct concentrations ranging between pg and $\mathrm{ng} / \mathrm{mL}$ have been detected in African and Asian individuals (Allen et al., 1992; Diallo et al., 1995; Wang et al., 1996; Power et al., 2002). Aflatoxin albumin adducts have also been detected in the bronchoalveolar lavage (BAL) and serum of food-grain workers which correlated with the presence of Aspergillus and respiratory symptoms (Malik et al., 2014) while levels ranging between $4.8-12.5 \mathrm{ng} / \mathrm{mg}$ and $0.32-0.8 \mathrm{ng} / \mathrm{mg}$ were detected in BAL and serum, respectively from patients with chronic lung disease (Ali et al., 2013), suggesting that aflatoxins may be produced by Aspergillus during active infection. The presence of aflatoxin $\mathrm{B}_{1}$-albumin adducts in the blood plasma of Ghanaian villagers correlated with a significantly lower percentage of activated $\mathrm{T}$ cells and lower numbers of activated natural killer cells compared to unexposed individuals (Jiang et al., 2005). Treatment of hepatic cells with $40 \mu \mathrm{M}$ aflatoxin $\mathrm{B}_{1}$ activates the epidermal growth factor receptor (EGFR) which leads to downstream activation of PI3K-AKT/mTOR and 
induced autophagy (Xu et al., 2020). However, whether aflatoxinmediated activation of EGFR occurs in immune cells has yet to be determined.

\section{Epithelial Cells and Aflatoxin}

Aflatoxins have a significant effect on the integrity of epithelial barriers. Aflatoxin $\mathrm{M}_{1}$ is a hydroxylated metabolite of aflatoxin $\mathrm{B}_{1}$ which is detectable in a variety of dairy products (Bahrami et al., 2016). Differentiated gastrointestinal epithelial cells exhibit significant reductions in trans-epithelial electrical resistance (TEER) following exposure to aflatoxin $\mathrm{B}_{1}(100 \mu \mathrm{M})$ and $\mathrm{M}_{1}(0.12-12 \mu \mathrm{M})$ which correlated with a reduction in the expression of tight junction proteins and decreased viability (Romero et al., 2016; Gao et al., 2017). The effects of aflatoxin (and other fungal toxins) on barrier integrity are summarised in Figure 3.

\section{Monocytes, Macrophages, and Aflatoxin}

Human monocytes exposed to aflatoxin $B_{1}$ exhibit a significant reduction in the ability to phagocytose and kill Candida albicans in vitro (Cusumano et al., 1996), while aflatoxin $\mathrm{M}_{1} \quad(25$ and $50 \mu \mathrm{g} / \mathrm{kg}$ body weight) administered to mice over a 28 day period caused a reduction in the phagocytosis of Escherichia coli by monocytes (Shirani et al., 2018).

The production of nitric oxide (NO) by immune cells inhibits the growth of invading microbes and regulates inflammatory innate immune responses (Bogdan et al., 2000). CD14-mediated recognition of LPS by macrophages drives the production of $\mathrm{NO}$ which induces cytotoxic effects in numerous pathogens. Application of aflatoxin $\mathrm{B}_{1}(0-50 \mu \mathrm{M})$ to murine peritoneal macrophages prior to LPS stimulation suppressed the expression of CD14 and reduced the production of NO (Moon and Pyo, 2000). Aflatoxin $B_{1}, B_{2}$ and their metabolic products aflatoxin $M_{1}$ and $M_{2}$ have similar effects on NO production. Treatment of murine macrophages with $30 \mu \mathrm{M}$ of these molecules caused a modest but significant $(\sim 5-40 \%)$ reduction in NO production.

Interestingly, when macrophages are exposed to a combination of $15 \mu \mathrm{M}$ aflatoxin $\mathrm{B}_{1}$ and $\mathrm{M}_{1}$, or aflatoxin $\mathrm{B}_{2}$ and $\mathrm{M}_{2}$, a synergistic reduction in $\mathrm{NO}$ production occurs which was more pronounced when compared to aflatoxin $\mathrm{M}_{1}$ or $\mathrm{M}_{2}$ alone (Bianco et al., 2012). These observations suggest that aflatoxins and their metabolic products may work co-operatively to suppress macrophage function.

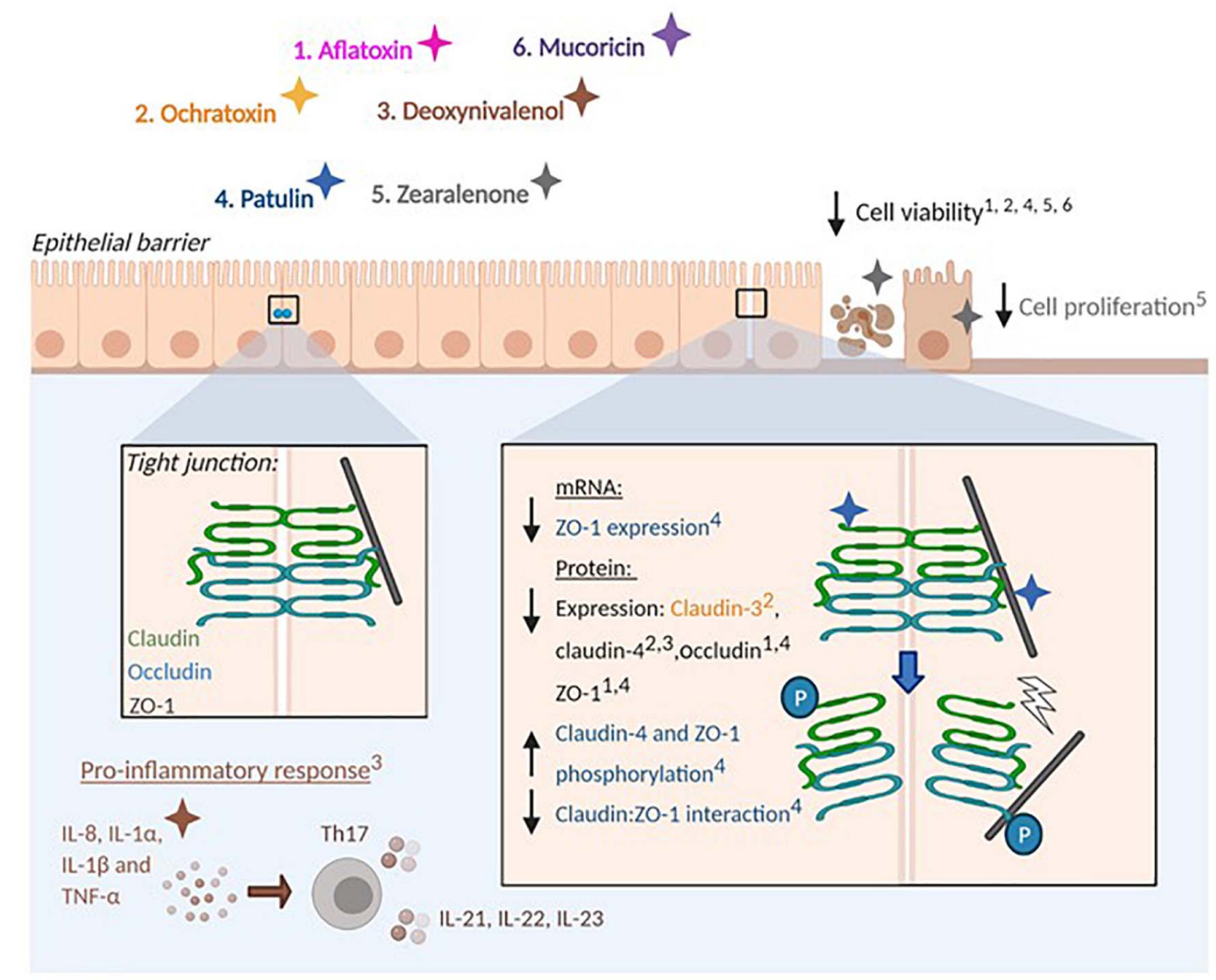

FIGURE 3 | Effect of mycotoxins and protein toxins on barrier integrity. Fungal toxins that influence epithelial barrier integrity are represented by colours: 1. Aflatoxin (pink), 2. Ochratoxin (orange), 3. Deoxynivalenol (brown), 4. Patulin (blue), 5. Zearalenone (grey). 6. Mucoricin (purple). Mycotoxins impair epithelial barrier integrity by altering the production of tight junction proteins (Claudins, Occludin and Zonula occludens-1) by epithelial cells. Arrows denote the promotion or reduction of indicated processes. Numbers in superscript identify processes affected by specific toxins. Protein phosphorylation is indicated (P). Mycotoxins also stimulate pro-inflammatory responses at mucosal surfaces and impair barrier integrity in a tight junction-independent manner by reducing cell viability and proliferation. 
Aflatoxin $\mathrm{B}_{1}$ does not promote macrophage apoptosis but rather induces cell cycle arrest. J774A.1 murine macrophages treated with $50 \mu \mathrm{M}$ aflatoxin $\mathrm{B}_{1}$ for $24 \mathrm{~h}$ induced a significant switch from G0/G1 phase to $S$ phase (Bianco et al., 2012). While apoptosis is not induced by aflatoxin $B_{1}$, an autophagic response and release of macrophage extracellular traps (METs) was observed in a ROS-dependent manner (An et al., 2017). Finally, aflatoxin $B_{1}, B_{2}$, and $G_{2}$ supressed the ability of primary rat peritoneal macrophages to phagocytose and kill C. albicans in vitro (Cusumano et al., 1990).

\section{Neutrophils and Aflatoxin}

Human neutrophils treated with $32 \mathrm{nM}$ aflatoxin $\mathrm{B}_{1}$ exhibited a depletion of intracellular ATP and a non-significant increase in apoptosis (Mehrzad et al., 2020), while treatment of polymorphonuclear leukocytes with $160 \mathrm{nM}$ aflatoxin $\mathrm{B}_{1}$ induced a significant reduction in ROS production and chemotactic ability compared to controls (Ubagai et al., 2008). Studies also demonstrate a reduction in the chemotactic responses of neutrophils isolated from the blood of piglets, and a reduction in phagocytosis and intracellular killing of Staphylococcus aureus and $E$. coli in neutrophils isolated from dairy cows (Silvotti et al., 1997; Mehrzad et al., 2011).

\section{Dendritic Cells and Aflatoxin}

Human monocyte-derived dendritic cells treated with $32 \mathrm{nM}$ aflatoxin $B_{1}$ upregulate the expression of toll-like receptor (TLR) $2 / 4$ and the secretion of IL- $1 \beta$ and IL- 6 within $2 \mathrm{~h}$ (Mohammadi et al., 2014). In contrast, porcine monocyte-derived dendritic cells treated with $32 \mathrm{nM}$ aflatoxin $\mathrm{B}_{1}$ for $12 \mathrm{~h}$ exhibited impaired phagocytosis and reduced expression of co-stimulatory CD40 although the secretion of IL- $1 \beta$, IL- 8 , IL-10, and TNF- $\alpha$ remained unchanged. After $24 \mathrm{~h}$ of exposure an impairment in the ability to induce $\mathrm{T}$ cell proliferation was observed (Mehrzad et al., 2014). The effects of aflatoxin on host immune responses are summarised in Figure 2.

\section{OCHRATOXIN}

The ochratoxins contain a 3,4-dihydro-3-methylisocoumarin moiety coupled to $\beta$-phenylalanine. While three ochratoxins are known to exist (A, B, and $\mathrm{C})$, ochratoxin $\mathrm{A}$ $(N-\{[(3 R)-5$-chloro-8-hydroxy-3-methyl-1-oxo-3,4-dihydro-

$1 H$-isochromen-7-yl]carbonyl $\}$-Lphenylalanine: Figure 1C) is the most prevalent. Ochratoxin A was discovered in Aspergillus ochraceus in 1965 (van der Merwe et al., 1965) and is produced by numerous Aspergillus and Penicillium species (Abarca et al., 1994; Bayman et al., 2002; Cabañes et al., 2010). Ochratoxins are associated with nephrotoxicity in humans and in animal models (Boorman et al., 1992; Betbeder et al., 1995; Maaroufi et al., 1995) and exert broad immunotoxicity on the mammalian immune system (Thurston et al., 1986; Richard, 1991). Exposure of piglets to sub-chronic levels $(0.05 \mathrm{mg} / \mathrm{kg}$ in feed) of ochratoxin A for 30 days caused a reduction in $\mathrm{NF}-\kappa \mathrm{B}$ gene expression in duodenum and in the expression of several cytokines including IL-8, IL-17A, and IL-18 in duodenum and colon (Marin et al., 2017).

\section{Epithelial Barriers and Ochratoxin}

Ochratoxin A has a significant effect on the integrity of the gastrointestinal barrier. Caco-2 monolayers treated with $100 \mu \mathrm{M}$ ochratoxin A exhibited a time-dependent reduction in TEER between 4 and $24 \mathrm{~h}$ which correlated with an absence of claudin2 (McLaughlin et al., 2004). Similarly, application of 2, 4, and $8 \mu \mathrm{M}$ ochratoxin A to porcine intestinal epithelial cells stimulated apoptosis in a dose-dependent manner (Wang et al., 2017).

\section{Macrophages and Ochratoxin}

Mice that received intraperitoneal administration ( 3 and $6 \mathrm{mg} / \mathrm{kg}$ body weight per day) of ochratoxin A for up to 15 days produced monocytes with an impaired ability to phagocytose E. coli (Müller et al., 1995), while daily oral administration $(1.5 \mathrm{mg} / \mathrm{kg}$ body weight) over 17 weeks impaired the chemotactic activity of peritoneal macrophages and production of IL- 1 and TNF- $\alpha$ (Dhuley, 1997).

Bovine macrophages treated with $9 \mu \mathrm{M}$ ochratoxin A for 6 and $24 \mathrm{~h}$ differentially expressed genes involved in oxidative stress responses and apoptosis (Brennan et al., 2017). In contrast however, a recent in vitro study conducted on porcine alveolar macrophages revealed a temporal, biphasic response to $2.5 \mu \mathrm{M}$ ochratoxin A. At $24 \mathrm{~h}$ post-treatment, expression of IL-6 and TNF- $\alpha$ was significantly upregulated and the majority of macrophages were pro-inflammatory $\mathrm{CD}^{+} 0^{+} \mathrm{M} 1$ cells. By $72 \mathrm{~h}$ post-treatment, macrophage viability was significantly reduced, IL- 6 and TNF- $\alpha$ expression returned to baseline levels and a significant switch in macrophage polarisation to a CD208 ${ }^{+}$antiinflammatory M2 phenotype was observed (Su et al., 2019).

\section{Neutrophils and Ochratoxin}

Mice that received a single oral dose $(10 \mathrm{mg} / \mathrm{kg}$ body weight) of ochratoxin A exhibited increased oxidative damage of parenchymal organs and neutrophil infiltration into the duodenum after $24 \mathrm{~h}$ (Ferrante et al., 2006). Notably however, the phagocytic ability of neutrophils was significantly reduced after 17 days (Müller et al., 1995), suggesting that cellular function was impaired. Application of ochratoxin A to human neutrophils in vitro stimulated a dose-dependent activation of the oxidative burst response from $2 \mathrm{~h}$, an increase in the level of intracellular calcium from $4 \mathrm{~h}$ and adenosine triphosphate depletion and necrosis from 8 and 20 h, respectively (Kupski et al., 2016), while $25 \mu \mathrm{M}$ treatment impaired chemotactic and NO responses (Richetti et al., 2005).

\section{Inflammatory Disease and Ochratoxin}

Despite evidence showing that ochratoxins have an immunosuppressive effect, pro-inflammatory responses were observed following gastric intubation of $49.5 \mathrm{nM}$ ochratoxin A which promoted the progression of rheumatoid arthritis (RA) in vivo (Jahreis et al., 2017). An increase in the prevalence and clinical severity of RA was observed in a collagen-induced murine model which correlated with increased production of IL-1 $\beta$ and IL-6 in inflamed joints and IFN- $\gamma$ and IL-17 in splenocytes. Furthermore, increased production of IL- $1 \beta$, IL- 6 , and TNF- $\alpha$ from activated murine macrophages was observed in response 
to 2.5-250 nM ochratoxin A and facilitated the differentiation of naïve T cells into Th1 cells in vitro (Jahreis et al., 2017). The modulatory influence of ochratoxins on host immune responses are summarised in Figure 2.

\section{FUMONISIN}

The fumonisins are polyketides which are structurally similar to sphingosine. Fumonisin $\mathrm{B}_{1} \quad\left(\left(2 S, 2^{\prime} S\right)-2,2^{\prime}\right.$ $\{[(5 S, 6 R, 7 R, 9 R, 11 S, 16 R, 18 S, 19 S)-19$-Amino- $11, \quad 16, \quad 18-$ trihydroxy-5,9-dimethylicosane-6,7-diyl]bis[oxy(2-oxoethane-2, 1-diyl)]\}disuccinic acid: Figure 1D) was discovered in 1988 and is produced by numerous species of Fusarium including Fusarium oxysporum. Fumonisins and fumonisin-producing fungi have broad immunotoxic effects on livestock in vitro and in vivo including reduced number, viability and phagocytic ability of macrophages, blockade of dendritic cell maturation and antigen presentation, diminished antigen specific $\mathrm{T}$ cell responses and a reduction in the size of spleen and thymus (Marijanovic et al., 1991; Qureshi and Hagler, 1992; Chatterjee et al., 1995; Qureshi et al., 1995; Pierron et al., 2016).

\section{Macrophages and Fumonisin}

Fumonisins exert a broad inhibitory effect on the function of livestock macrophages. Swine alveolar macrophages exposed to different concentrations of fumonisin $\mathrm{B}_{1}$ exhibited DNA laddering (7 and $35 \mu \mathrm{M})$ consistent with apoptosis, impaired phagocytosis $(69 \mathrm{nM}$ and $0.7 \mu \mathrm{M}$ ) and a reduction in the level of IL-1 $\beta$ and TNF- $\alpha$ gene expression (2.7 and $14 \mu \mathrm{M})$ in vitro (Liu et al., 2002). Similarly, a reduction in IL-1 $\beta$, IL6 , and IL-8 gene expression was observed in the spleen of piglets that received dietary $(6 \mathrm{mg} / \mathrm{kg})$ fumonisin $B_{1}$ over 5 weeks (Grenier et al., 2011). Chicken peritoneal macrophages exhibited reduced phagocytic capacity, cytoplasmic blebbing, nuclear disintegration, and significant cell death in response to fumonisin $B_{1}$ in vitro (Qureshi and Hagler, 1992).

\section{Dendritic Cells and Fumonisin}

Piglets that received an oral dose of fumosinin $B_{1}(1 \mathrm{mg} / \mathrm{kg}$ body weight) for 10 days and were subsequently exposed to purified F-4 fimbriae from enterotoxigenic $E$. coli exhibited prolonged intestinal infection, reduced intestinal expression of IL-12p40 and an impairment in the function of intestinal antigen presenting cells. Moreover, dendritic cells treated with fumosinin $\mathrm{B}_{1}$ were impaired in their ability to activate $\mathrm{T}$ cells in vitro (Devriendt et al., 2010). Collectively, these data suggest that Fumonisin $B_{1}$ dampens the immune response to pathogenic enteric bacteria through the modulation of immune cell activity (Devriendt et al., 2010). The impact of fumonisins on host immune responses are summarised in Figure 2.

\section{T-2 TOXIN}

T-2 toxin (Figure 1E) is a type A member of the trichothecene family of mycotoxins produced by many of the same fungi that also produce deoxynivalenol (Fusarium, Isaria, Microcyclospora, Myrothecium, Peltaster, Spicellum, Stachybotrys, Trichoderma, and Trichothecium) (Venkatasubbaiah et al., 1995; Kikuchi et al., 2004; McCormick et al., 2011; Surup et al., 2014). T-2 toxin is a potent inhibitor of protein synthesis and is associated with conditions including alimentary toxic aleukia and Kashin-Beck disease (Bony et al., 2007; Wan et al., 2015; Li et al., 2016).

\section{Macrophages and T-2 Toxin}

Porcine alveolar macrophages treated with $30 \mathrm{nM}$ T-2 toxin for $16 \mathrm{~h}$ exhibited a significant increase in apoptosis concomitant with decreased mitochondrial membrane potential (Seeboth et al., 2012). Moreover, pre-treatment of the same cells with $3 \mathrm{nM}$ T-2 toxin for $1 \mathrm{~h}$ followed by exposure to TLR 2, 4 , and $2 / 6$ agonists for $16 \mathrm{~h}$ induced a significant reduction in TLR2, TLR4, and TLR2/6 mRNA expression, and reduced production of IL-1 $\beta$ and NO compared with non-pre-treated controls (Seeboth et al., 2012).

Treatment of human macrophages with $10 \mathrm{nM} \quad \mathrm{T}-2$ toxin significantly reduced the oxidative burst response and phagocytosis of fluorescent microspheres, while pre-treatment with $10 \mathrm{nM}$ T-2 toxin followed by LPS stimulation caused a significant reduction in the secretion of TNF- $\alpha$ compared with non-pre-treated controls (Hymery et al., 2009). These observations suggest that T-2 toxin may diminish the hosts ability to recognise and respond to pathogens which may increase susceptibility to infection.

\section{Dendritic Cells, Monocytes, and T-2 Toxin}

Dendritic cells are critical conduits that link innate and adaptive immunity. Treatment of immature human monocyte-derived dendritic cells with $1 \mu \mathrm{M}$ T-2 toxin in vitro reduced viability by $90 \%$ after $24 \mathrm{~h}$, while dendritic cells pre-treated with LPS and $10 \mathrm{nM}$ T-2 toxin exhibited a marked reduction in the expression of the dendritic cell maturation marker CD86 and reduced secretion of IL-10 and IL-12 when compared with LPS stimulation alone (Hymery et al., 2006).

Human primary monocytes are sensitive to significantly lower concentrations of T-2 toxin than differentiated macrophages or dendritic cells. Monocytes treated with $0.1 \mathrm{nM}$ T-2 toxin for $24 \mathrm{~h}$ exhibited a significant decrease in viability compared to controls, while approximately 10 -fold higher concentrations were required to significantly reduce the viability of macrophages and dendritic cells (Hymery et al., 2006, 2009; Seeboth et al., 2012). As well as cytotoxic effects, cellular differentiation is also negatively affected by T-2 toxin. Human primary monocytes cultured with T-2 toxin (0.1-10 nM) and granulocyte macrophagecolony stimulating factor (GM-CSF) significantly reduced the expression of CD71 (a marker of macrophage differentiation) compared to cells cultured with GM-CSF alone (Hymery et al., 2009). The differentiation of monocytes into dendritic cells can be monitored by quantification of CD14 (monocyte marker) and CD1a (dendritic cell marker). Human primary monocytes cultured with GM-CSF and IL- 4 were $85 \% \mathrm{CD}^{+}{ }^{+}$after $48 \mathrm{~h}$, while $80 \%$ of monocytes similarly cultured in the presence of 10 nM T-2 toxin remained CD14 ${ }^{+}$(Hymery et al., 2009). The 
impact of T-2 toxin on host immune responses is summarised in Figure 2.

\section{DEOXYNIVALENOL}

Deoxynivalenol $((3 \alpha, 7 \alpha)$-3,7,15-trihydroxy-12,13-epoxytrichothe -9-en-8-one: Figure $\mathbf{1 F}$ ) is a type $B$ member of the trichothecene family of mycotoxins and has been isolated from numerous genera of fungi including Fusarium, Isaria, Microcyclospora, Myrothecium, Peltaster, Spicellum, Stachybotrys, Trichoderma, and Trichothecium (Venkatasubbaiah et al., 1995; Kikuchi et al., 2004; McCormick et al., 2011; Surup et al., 2014). Like T-2 toxin, deoxynivalenol is also a potent inhibitor of eukaryotic protein synthesis and although it is considered to be a less potent toxin than T-2, it exerts significant toxicity on humans and animals and has the greater effect on innate immunity. Acute symptoms following ingestion include: diarrhoea, vomiting, nausea, and gastroenteritis earning deoxynivalenol the name of "vomitoxin" (Forsyth et al., 1977; Friend et al., 1982; Prelusky and Trenholm, 1993; Luo, 1994; Iverson et al., 1995).

\section{Gut Epithelium, Inflammatory Bowel Disease, and Deoxynivalenol}

Like many mycotoxins, deoxynivalenol causes disruption to intestinal barriers. Deoxynivalenol-induced activation of p44/42 ERK signalling inhibited the expression of claudin-4 in IPEC-1 intestinal epithelial cells, resulting in the loss of gastrointestinal barrier integrity (Pinton et al., 2010). In addition to perturbation of the gut mucosal barrier deoxynivalenol also induces phenotypes associated with inflammatory bowel disease in vitro and in vivo. IPEC-1 cells treated with $10 \mu \mathrm{M}$ deoxynivalenol induced significant expression of the proinflammatory cytokines IL- 8 , IL- $1 \alpha$, IL- $1 \beta$, and TNF- $\alpha$ by $4 \mathrm{~h}$ which correlated with the activation of genes associated with a pathogenic, pro-inflammatory Th17 response (IL-21, IL-22, IL23) (Cano et al., 2013). Furthermore, a rat model of DSS-induced colitis exposed to $8 \mathrm{mg} / \mathrm{kg}$ of deoxynivalenol in their diet for 4 weeks induced a more rapid and severe onset of colitis than controls and induced significant increases in pro-inflammatory markers (myeloperoxidase, CXCL-1, and IL-1 $\beta$ ) (Payros et al., 2020). These observations suggest that deoxynivalenol may be a risk factor in the onset of inflammatory bowel disease and may involve Th17 responses.

\section{Macrophages and Deoxynivalenol}

Though the trichothecenes are potent inhibitors of protein synthesis, deoxynivalenol is capable of stabilising mRNA transcripts that encode pro-inflammatory cytokines through the interaction of HuR/ELAVL1 RNA binding protein with the $3^{\prime}$ untranslated region of mRNA (Wong et al., 2001; Choi et al., 2009). Indeed, treatment of LPS-stimulated RAW276.4 macrophages with $0.84 \mu \mathrm{M}$ deoxynivalenol for $6 \mathrm{~h}$ upregulated the expression of IL-1 $\beta$, IL-6, and TNF- $\alpha$ (He et al., 2013).

Cyclooxygenase-2 (COX-2) is a rate limiting enzyme that catalyses the production of prostaglandins and thromboxane $\mathrm{A}_{2}$, both of which play a key role in the inflammatory response
(Vane et al., 1998; Smith et al., 2000). Expression of COX2 , IL-8, and TNF- $\alpha$ mRNA in response to deoxynivalenol is driven by ERK and p38 signalling, and in part mediates the expression of IL- 6 and IL- $1 \beta$ with mRNA stability also promoted by p38 (Moon and Pestka, 2002; Chung et al., 2003; Islam et al., 2006). As well as the induction of pro-inflammatory responses, deoxynivalenol also induces caspase- 3 activation in a dosedependent manner in J7741.A murine macrophages, suggestive of apoptosis (Marzocco et al., 2009). Independent inhibition of ERK and p38 signalling confirmed that these factors also play a role in apoptotic cell death induced by deoxynivalenol (Yang et al., 2000; Marzocco et al., 2009).

\section{Neutrophils, in vivo Models, and Deoxynivalenol}

Deoxynivalenol reduces chemotaxis, IL-8 secretion and phagocytic functionality of LPS-stimulated porcine neutrophils which correlated with p38 phosphorylation, caspase- 3 activation and apoptosis (Gauthier et al., 2013). Mice that received an oral gavage of deoxynivalenol (5-25 $\mathrm{mg} / \mathrm{kg}$ body weight) robustly induced the expression of genes encoding IL-1 $\beta$, IL-6, TNF- $\alpha$, and $\mathrm{Th}_{1 / 2}$ cytokines in spleen tissue $2 \mathrm{~h}$ post treatment (Zhou et al., 1997). A single oral dose $(12.5 \mathrm{mg} / \mathrm{kg}$ body weight) of deoxynivalenol administered to mice induced significant production of IL-1 $\beta$, IL- 6 , and TNF- $\alpha$ mRNA at 3-6 h which correlated with JNK, ERK1/2, and p38 phosphorylation (Zhou et al., 2003).

\section{NF- $\kappa B$ and Deoxynivalenol}

Nuclear factor kappa-B is a target of deoxynivalenol, however, there are conflicting reports regarding its effect. Mice given a single oral dose of deoxynivalenol ( $25 \mathrm{mg} / \mathrm{kg}$ body weight) induced nuclear translocation of p50 and c-Rel NF-кB subunits in spleen tissue (Zhou et al., 2003). Conversely, RAW264.7 macrophages treated with 0.2-3.3 $\mu \mathrm{M}$ deoxynivalenol and stimulated with LPS for $6 \mathrm{~h}$ exhibited significant reductions in NF- $\kappa \mathrm{B}$ luciferase reporter activity while higher concentrations 1.7-3.3 $\mu \mathrm{M}$ inhibited I $\mathrm{I} \mathrm{B} \alpha$ phosphorylation which correlated with MyD88 inhibition (Sugiyama et al., 2016). The effects of deoxynivalenol on host immune responses are summarised in Figure 2.

\section{PATULIN}

Patulin (4-hydroxy-4H-furo[3,2-c]pyran-2(6H)-one: Figure 1G) is a polyketide most commonly produced by the fungal genera Penicillium and Aspergillus (Frisvad, 2018). Patulin is produced in a 10-step biosynthetic pathway that is controlled by 15 genes (Puel et al., 2010; Li et al., 2019). Mice that received an intraperitoneal injection of patulin ( $1 \mathrm{mg} / \mathrm{kg}$ body weight) exhibited a significant increase in the level of ROS in hepatic tissue (Song et al., 2014; Guerra-Moreno and Hanna, 2017; Sun et al., 2018) while $2 \mu \mathrm{M}$ patulin induced autophagy in HepG2 liver cells in vitro (Sun et al., 2018), suggesting that patulin may have a detrimental impact on liver function in addition to immunotoxicity. 


\section{Epithelial Cells and Patulin}

Intestinal barriers are a major target of patulin. Caco-2 intestinal epithelial cells exposed to $50 \mu \mathrm{M}$ patulin for 1-24 h exhibited reductions in TEER, cell viability and reduced expression of zonula occludens-1 (ZO-1) and myosin light chain-2 (MLC2), but not occludin, claudin-1 or claudin-3 (Assunção et al., 2016). Similar treatment conditions induced a reduction in ZO-1 and claudin- 4 protein at cell-cell junctions after $24 \mathrm{~h}$, while the interaction between $\mathrm{ZO}-1$ and claudin- 4 was abrogated after $72 \mathrm{~h}$ (Kawauchiya et al., 2011), suggesting that barrier integrity is negatively affected by patulin.

Caco- 2 cells treated with $50 \mu \mathrm{M}$ patulin for $6 \mathrm{~h}$ exhibited a marked reduction in the expression of density-enhanced phosphatase-1 (DEP-1), and the peroxisome proliferatoractivated receptor gamma (PPAR $\gamma)$ transcription factor (Katsuyama et al., 2014). Knockdown of DEP-1 expression stimulated claudin-4 phosphorylation, a reduction in ZO-1 and the degradation of epithelial tight junctions (Katsuyama et al., 2014), suggesting that DEP-1 and PPAR $\gamma$ may be targeted by patulin to reduce gastrointestinal barrier function.

\section{Macrophages and Patulin}

Bovine macrophages reduced the expression of genes encoding IL-23, IL-10 and TGF- $\beta$ in response to $0.3 \mu \mathrm{M}$ patulin treatment and exhibited impaired ability to phagocytose mCherry-labelled Mycobacterium avium ssp. Paratuberculosis (Oh et al., 2015). Murine peritoneal macrophages exposed to $0.65-13 \mu \mathrm{M}$ patulin for $2 \mathrm{~h}$ also displayed an impairment in phagocytosis of Saccharomyces cerevisiae, reduced production of lysozyme and fungal killing (Bourdiol et al., 1990). Moreover, rats that received $0.1 \mathrm{mg} / \mathrm{kg}$ (body weight) of patulin per day displayed mitochondrial abnormalities after 60 days and an increase in the production of apoptotic bodies after 90 days (Özsoy et al., 2008). LPS-stimulated J774A.1 murine macrophages treated with $0.0065-6.5 \mathrm{pM}$ patulin exhibited reduced secretion of IL-6 and TNF- $\alpha$ in vitro (Loftus et al., 2016), while LPSdependent production of IL- 6 and NO was blocked in RAW264.7 macrophages in response to $5-100 \mu \mathrm{M}$ patulin and cell viability was markedly reduced at concentrations above $50 \mu \mathrm{M}$ in vitro (Tsai et al., 2016). Furthermore, the induction of NOD-, LRR-, and pyrin domain-containing protein 3 (NLRP3) and pro-IL$1 \beta$ in LPS-primed J774.1 macrophages was reduced by patulin, suggesting that inflammasome responses are also negatively affected (Tsai et al., 2016).

\section{Glutathione and Innate Immune Suppression by Patulin}

Patulin-induced modulation of intracellular glutathione (GSH) plays a major role in immunosuppression. Patulin depletes intracellular pools of GSH in CD3 and CD28 antibody-activated human peripheral blood mononuclear cells which correlated with a reduction in cytokine secretion. Indeed, treatment with $81 \mathrm{nM}$ patulin was sufficient to reduce secretion of IFN- $\gamma$ and IL-10, while a higher concentration $(0.65 \mu \mathrm{M})$ was required to reduce the secretion of IL-4 and IL-13 (Luft et al., 2008). TLR ligandinduced secretion of IL- 6 from murine RAW264.7 and primary peritoneal macrophages was blocked by pre-treatment with $1 \mu \mathrm{M}$ patulin and rescued by the addition of GSH (Tsai et al., 2016).

The immunotoxicity of patulin is in part due to the induction of mitochondrial dysfunction which is dependent upon GSH depletion. The application of $1 \mu \mathrm{M}$ patulin to rat hepatocytes was sufficient to induce rapid depletion of GSH (within $20 \mathrm{~min}$ ), while $1 \mathrm{mM}$ patulin induced the production of ROS, depolarisation of the mitochondrial membrane, an increase in the level of intracellular calcium and intracellular acidification (Barhoumi and Burghardt, 1996). Similarly, $1 \mu \mathrm{M}$ patulin induced mitochondrial translocation of p62 (autophagy marker) and mitophagy in murine RAW264.7 macrophages (Tsai et al., 2016). The suppressive effects of patulin on host immune responses are summarised in Figure 2.

\section{ZEARALENONE}

Zearalenone $\quad((3 S, 11 E)$-14,16-dihydroxy-3-methyl-3,4,5,6,9,10hexahydro-1H-2-benzoxacyclotetradecine-1,7 $(8 H)$-dione:

Figure $\mathbf{1 H}$ ) is produced by numerous species of Fusarium fungi (Hestbjerg et al., 2002; Kim et al., 2005; EFSA, 2013). Zearalenone and its metabolic products are non-steroidal oestrogenic mycotoxins that bind to oestrogen receptors, thereby influencing the proliferation of oestrogen-dependent cells in vitro. Oestrogen-dependent MCF-7 breast cancer cells treated with zearalenone or its derivatives $\alpha$-zearalenol or $\beta$-zearalenol at concentrations between 6.25 and $12.5 \mu \mathrm{M}$ undergo significant cellular proliferation compared with untreated controls (Tatay et al., 2018). In addition to this agonist response, zearalenone also exerts broad-ranging toxicity on host cells through a variety of mechanisms discussed below.

\section{Epithelial Cells, Macrophages, and Zearalenone}

In vitro studies of kidney and colonic epithelial cells demonstrate that concentrations of zearalenone between 1 and $60 \mu \mathrm{M}$ are sufficient to reduce cellular proliferation, inhibit DNA, RNA and protein synthesis by $50 \%$ and induce lipid peroxidation (Ghédira-Chékir et al., 1999; Abid-Essefi et al., 2004; Kouadio et al., 2005). The production of apoptotic bodies occurs at similar concentrations (Abid-Essefi et al., 2003), suggesting that programmed cell death is induced.

Porcine jejunum enterocytes treated with $25 \mu \mathrm{M}$ zearalenone for $24 \mathrm{~h}$ upregulated the production of caspase-1, pro-IL-1 $\beta$, and pro-IL-18 mRNA transcripts while an increase in ROS production and reduction in mitochondrial membrane potential and cell viability was observed after $48 \mathrm{~h}$ (Fan et al., 2017, 2018).

Mice that received an oral gavage of zearalenone $(20 \mathrm{mg} / \mathrm{kg}$ body weight) once daily for one week displayed alterations in the structure of the intestinal mucosa while the expression of $\beta$-defensin, mucin-1, mucin-2, IL- $1 \beta$, TNF- $\alpha$, and secretory immunoglobulin A were significantly increased (Wang et al., 2018). These observations suggest that zearalenone reduces the viability of cells involved in the maintenance of intestinal barrier function while stimulating a pro-inflammatory response. Mice given $4.5 \mathrm{mg} / \mathrm{kg}$ bodyweight of zearalenone for 1 week 
expressed IL-1 $\beta$, IL-18, and MPO mRNA transcripts and NLRP3 protein in colonic tissue and exhibited colitis-like symptoms (Fan et al., 2018).

In contrast to epithelial cells, relatively little is known about the biological activity of zearalenone on macrophages. However, murine RAW 264.7 macrophages stimulated with LPS for $16 \mathrm{~h}$ were observed to upregulate the expression of genes encoding IL$1 \beta$, IL- 6 , and TNF- $\alpha$ in response to $100 \mathrm{nM}$ zearalenone in vitro (Pestka and Zhou, 2006).

\section{Immunotoxicity of Zearalenone Metabolites}

Once ingested, zearalenone can be metabolised into several different compounds, each with differing levels of immunotoxicity. Although biotransformation of zearalenone occurs predominantly in the liver, human intestinal epithelial cells can also metabolise zearalenone into $\alpha$-zearalenol and $\beta$-zearalenol in vitro (Videmann et al., 2008) and both of these metabolites are detectable in human urine after $24 \mathrm{~h}$ following oral administration of zearalenone (Mirocha et al., 1981). Both $\alpha$-zearalenol and $\beta$-zearalenol caused a reduction in IL-8 secretion and cell viability in primary porcine neutrophils that was more potent than that induced by zearalenone (Marin et al., 2010), suggesting that the products of zearalenone metabolism may exert a greater influence on host immunity. The immunomodulatory effects of zearalenone are summarised in Figure 2.

\section{COMBINATORIAL EXPOSURE TO MYCOTOXINS}

Multiple mycotoxins can be produced from a single species of fungi, and it is not uncommon for foodstuffs to be simultaneously contaminated with multiple species of mycotoxin-producing fungi. Indeed, combinations of mycotoxins are detectable in contaminated food (Alshannaq and $\mathrm{Yu}, 2017$; Jin et al., 2021; Xiong et al., 2021). Accordingly, it is feasible that the ingestion of contaminated foodstuff may result in exposure to multiple toxins which may exacerbate immunotoxicity.

Intestinal epithelial cells respond to a combination of aflatoxin $\mathrm{M}_{1}$ and ochratoxin $\mathrm{A}$ (12 and $10 \mu \mathrm{M}$, respectively) by upregulating the expression of genes encoding IL- $1 \alpha$, IL- $1 \beta$, IL6 , TNF- $\alpha$, and IFN- $\alpha$ when compared with aflatoxin $M_{1}$ alone (Gao et al., 2020b), while a combination of the same mycotoxins (12 and $20 \mu \mathrm{M}$, respectively) reduces the expression of claudin3 , claudin-4, occludin and ZO-1 when compared to individual treatment (Gao et al., 2017). In contrast, porcine intestinal enterocytes treated for $48 \mathrm{~h}$ with a combination of deoxynivalenol and fumonisin $B_{1}(0.5$ and $20 \mu \mathrm{M}$, respectively), zearalenone and fumonisin $B_{1}$ (10 and $20 \mu \mathrm{M}$, respectively), or a mixture comprising all three toxins exhibited reduced cellular viability in vitro. Importantly, the concentration of each individual toxin was non-cytotoxic, suggesting that exposure to mycotoxins at seemingly non-toxic concentrations can exert toxicity when combined (Wan et al., 2013).
Swine alveolar macrophages treated with a combination of ochratoxin $A$ and aflatoxin $B_{1}$ (1 and $0.5 \mu \mathrm{M}$, respectively) for $48 \mathrm{~h}$ displayed a reduction in the level of intracellular GSH and phagocytic index (Hou et al., 2018).

Bovine macrophages treated with a combination of ochratoxin A $(8.9 \mu \mathrm{M})$ and patulin $(0.32 \mu \mathrm{M})$ downregulated the expression of genes encoding DNA methyltransferase 3a (DNMT-3a) and histone deacetylase 3 (HDAC-3), suggesting that combinatorial exposure may modulate epigenetic processes (Oh et al., 2013).

\section{PEPTIDE TOXINS: CANDIDALYSIN}

Candida albicans is a common commensal of the human microbiota which can become pathogenic when host immunity is compromised. Candidalysin (SIIGIIMGILGNIPQVIQIIMSIVKAFKGNK) is a peptide toxin generated from its parent protein (Ecelp) via enzymatic processing by fungal kexins and secreted from the invasive hyphal morphology of C. albicans (Moyes et al., 2016; Richardson et al., 2018a; Naglik et al., 2019). Candidalysin is amphipathic, adopts an $\alpha$-helical structure, and permeabilises artificial membranes through pore-formation, thus damaging host cells (Moyes et al., 2016).

\section{Epithelial Cells and Candidalysin}

In oral and vaginal epithelial cells, 15-70 $\mu \mathrm{M}$ candidalysin induces the release of lactate dehydrogenase and other alarmins (Moyes et al., 2016; Richardson et al., 2018b; Ho et al., 2020), which are characteristics of cell damage and membrane destabilisation. Candidalysin $(1.5-70 \mu \mathrm{M})$ activates epithelial immunity via two distinct mitogen-activated protein kinase (MAPK) signalling pathways; 38 and ERK1/2 (Moyes et al., 2010, 2016), with ERK1/2 being driven by activation of the EGFR (Ho et al., 2019). This leads to cytokine release, particularly G-CSF, GM-CSF, and IL-6, which is predominantly directed by the activator protein-1 (AP-1) transcription factor c-Fos and regulated by the MAPK phosphatase MKP1 (Ho et al., 2019). MAPK-dependent release of cytokines and damage-induced release of IL-1 family members (e.g., IL$1 \alpha / \beta)$ induces downstream innate immune cellular responses, including neutrophil recruitment and innate Type-17 immunity (comprising $\gamma \delta$-T cells and "natural" $\mathrm{CD} 4^{+} \mathrm{TCR} \alpha \beta^{+} \mathrm{T}$ cells). These cells are critical for protection against mucosal candidiasis in both murine models and in human antifungal immunity (Verma et al., 2017). Notably, immune responses against C. albicans are not mediated by conventional activators of fungal immunity such as Dectin-1/CARD9 (Bishu et al., 2014) but predominantly by EGFR (Ho et al., 2019). A model of how candidalysin activates host immunity is presented in Figure 2.

The role of candidalysin during C. albicans gut infections is unclear. In vitro data indicate that C. albicans may translocate across the gut barrier using a combination of processes, including active penetration and cellular damage that may lead to loss of epithelial integrity (Allert et al., 2018). The current view is that candidalysin-induced epithelial damage is only required for C. albicans translocation via the transcellular route but not the 
TABLE 1 | Modulation of host defences by mycotoxins, peptide, and protein toxins.

\begin{tabular}{|c|c|c|}
\hline Toxin & Function & References \\
\hline Gliotoxin & $\begin{array}{l}\text { - Induces apoptosis (macrophages/dendritic cells/monocytes/eosinophils) } \\
\text { - Inhibits phagocytic function (macrophages/neutrophils) } \\
\text { - Induces ROS production (macrophages) } \\
\text { - Cytoskeletal remodelling (macrophages) } \\
\text { - Inhibits formation of lamellipodia (macrophages) } \\
\text { - Inhibits cytokine production (macrophages/dendritic cells/monocytes/eosinophils) } \\
\text { - Inhibits activation (neutrophils) } \\
\text { - Inhibits filopodia production (neutrophils) } \\
\text { - Induces F-actin reorganisation (neutrophils) } \\
\text { - Reduces ROS production (neutrophils) } \\
\text { - Inhibits NADPH oxidative burst (neutrophils) }\end{array}$ & $\begin{array}{l}\text { - Mullbacher and Eichner, } 1984 \\
\text { - Waring et al., } 1988 \\
\text { - Suen et al., } 2001 \\
\text { - Levin et al., } 2015 \\
\text { - Schlam et al., } 2016 \\
\text { - Orciuolo et al., } 2007 \\
\text { - Coméra et al., } 2007 \\
\text { - Tsunawaki et al., } 2004 \\
\text { - Stanzani et al., } 2005 \\
\text { - Fujihara et al., } 2002 \\
\text { - Johannessen et al., } 2005\end{array}$ \\
\hline Aflatoxins & $\begin{array}{l}\text { - Inhibits phagocytosis (macrophages) } \\
\text { - Inhibits NO production (macrophages) } \\
\text { - Induces cell cycle arrest (macrophages) } \\
\text { - Induces formation of METs } \\
\text { - Inhibits intracellular ROS (high dose: neutrophils) } \\
\text { - Induces intracellular ROS (macrophages/neutrophils) } \\
\text { - Inhibits chemotactic responses (neutrophils) } \\
\text { - Inhibits intracellular killing of pathogens (neutrophils) } \\
\text { - Induces cytokine expression (2 h: dendritic cells) } \\
\text { - Reduces phagocytic ability (12 h: dendritic cells) } \\
\text { - Inhibits T-cell activation (12 h: dendritic cells) } \\
\text { - Reduces TEER (epithelial cells) } \\
\text { - Reduces expression of tight junction proteins (epithelial cells) } \\
\text { - Increases paracellular permeability (epithelial cells) }\end{array}$ & $\begin{array}{l}\text { - Stanzani et al., } 2005 \\
\text { - Orciuolo et al., } 2007 \\
\text { - Bianco et al., } 2012 \\
\text { - An et al., } 2017 \\
\text { - Mehrzad et al., } 2020 \\
\text { - Ubagai et al., } 2008 \\
\text { - Mehrzad et al., } 2011 \\
\text { - Mohammadi et al., } 2014 \\
\text { - Mehrzad et al., } 2014 \\
\text { - Caloni et al., } 2012 \\
\text { - Gao et al., } 2017\end{array}$ \\
\hline Ochratoxin & $\begin{array}{l}\text { - Inhibits IL-1 } \alpha / T N F-\alpha \text { production in vivo (macrophages) } \\
\text { - Cell cycle arrest and induction of apoptotic genes (macrophages) } \\
\text { - Induces IL-1 } 1 \beta \text {, IL-6 and TNF- } \alpha \text { in vitro (macrophages) } \\
\text { - Induces necrosis (neutrophils) } \\
\text { - Reduces NO production (neutrophils) } \\
\text { - Reduces chemotactic responses (macrophages/neutrophils) } \\
\text { - Reduces phagocytic responses (neutrophils) } \\
\text { - Reduces TEER (epithelial cells) } \\
\text { - Inhibits expression of tight junction proteins (epithelial cells) }\end{array}$ & $\begin{array}{l}\text { - Dhuley, } 1997 \\
\text { - Brennan et al., } 2017 \\
\text { - Müller et al., } 1995 \\
\text { - Kupski et al., } 2016 \\
\text { - Richetti et al., } 2005 \\
\text { - McLaughlin et al., } 2004 \\
\text { - Wang et al., } 2017\end{array}$ \\
\hline Fumonisin & $\begin{array}{l}\text { - Induces apoptosis (macrophages) } \\
\text { - Inhibits phagocytic ability (macrophages) } \\
\text { - Inhibits expression and secretion of cytokines (macrophages) } \\
\text { - Inhibits maturation (dendritic cells) }\end{array}$ & $\begin{array}{l}\text { - Grenier et al., } 2011 \\
\text { - Qureshi and Hagler, } 1992 \\
\text { - Liu et al., } 2002 \\
\text { - Devriendt et al., } 2010\end{array}$ \\
\hline $\mathrm{T}-2$ & $\begin{array}{l}\text { - Induces apoptosis (macrophages) } \\
\text { - Inhibits NO production (macrophages) } \\
\text { - Inhibits oxidative burst (macrophages) } \\
\text { - Inhibits secretion of inflammatory cytokines (macrophages) } \\
\text { - Induces formation of balloon-like protrusions (BLPs: mice) } \\
\text { - Induces cell death (dendritic cells/monocytes) } \\
\text { - Inhibits maturation and activation (dendritic cells) } \\
\text { - Inhibits differentiation (monocytes) }\end{array}$ & $\begin{array}{l}\text { - Seeboth et al., } 2012 \\
\text { - Hymery et al., } 2009 \\
\text { - Chikina et al., } 2020 \\
\text { - Hymery et al., } 2006\end{array}$ \\
\hline Deoxynivalenol & $\begin{array}{l}\text { - Induces release of cytokines (macrophages/neutrophils/epithelial cells) } \\
\text { - Induces apoptosis (macrophages/neutrophils) } \\
\text { - Reduces chemotactic response (neutrophils) } \\
\text { - Reduces TEER and tight junction protein expression (epithelial cells) } \\
\text { - Induces Th17 immune response (epithelial cells) } \\
\text { - Induces colitis-like symptoms in rats }\end{array}$ & $\begin{array}{l}\text { - He et al., } 2013 \\
\text { - Moon and Pestka, } 2002 \\
\text { - Chung et al., } 2003 \\
\text { - Islam et al., } 2006 \\
\text { - Marzocco et al., } 2009 \\
\text { - Sugiyama et al., } 2016 \\
\text { - Gauthier et al., } 2013 \\
\text { - Pinton et al., } 2010 \\
\text { - Cano et al., } 2013 \\
\text { - Payros et al., } 2020\end{array}$ \\
\hline Patulin & $\begin{array}{l}\text { - Inhibits expression and secretion of cytokines (macrophages) } \\
\text { - Inhibits intracellular killing of fungi (macrophages) } \\
\text { - Induces apoptosis (macrophages/epithelial cells) } \\
\text { - Inhibits NO production (macrophages) } \\
\text { - Induces mitochondrial dysfunction and mitophagy (macrophages) } \\
\text { - Reduces TEER (epithelial cells) } \\
\text { - Inhibits expression of ZO-1 (epithelial cells) } \\
\text { - Inhibits ZO-1 and claudin-4 production (epithelial cells) }\end{array}$ & $\begin{array}{l}\text { - Oh et al., } 2015 \\
\text { - Bourdiol et al., } 1990 \\
\text { - Tsai et al., } 2016 \\
\text { - Luft et al., } 2008 \\
\text { - Assunção et al., } 2016 \\
\text { - Kawauchiya et al., } 2011\end{array}$ \\
\hline
\end{tabular}


TABLE 1 | Continued

\begin{tabular}{|c|c|c|}
\hline Toxin & Function & References \\
\hline Zearalenone & $\begin{array}{l}\text { - Induces inflammatory cytokines (macrophages/epithelial cells) } \\
\text { - Inhibits protein/DNA synthesis (epithelial cells) } \\
\text { - Induces apoptosis (macrophages/epithelial cells) } \\
\text { - Activates inflammasome (epithelial cells) } \\
\text { - Induces colitis-like symptoms in mice }\end{array}$ & $\begin{array}{l}\text { - Abid-Essefi et al., } 2003 \\
\text { - Kouadio et al., } 2005 \\
\text { - Pestka and Zhou, } 2006 \\
\text { - Fan et al., } 2017 \\
\text { - Fan et al., } 2018\end{array}$ \\
\hline Candidalysin & $\begin{array}{l}\text { - Induces NLRP3 inflammasome activation (macrophages) } \\
\text { - Damages plasma membranes (epithelial cells) } \\
\text { - Induces release of cytokines (epithelial cells/neutrophils/macrophages) } \\
\text { - Induces calcium influx (epithelial cells) } \\
\text { - Induces EGFR activation (epithelial cells) }\end{array}$ & $\begin{array}{l}\text { - Kasper et al., } 2018 \\
\text { - Verma et al., } 2017 \\
\text { - Moyes et al., } 2016 \\
\text { - Ho et al., } 2019\end{array}$ \\
\hline Mucoricin & $\begin{array}{l}\text { - Inhibits protein synthesis (N-glycosylase activity) } \\
\text { - Induces hypovolemic shock in mice } \\
\text { - Causes apoptosis and necrosis (murine lung and liver tissue) }\end{array}$ & • Soliman et al., 2021 \\
\hline
\end{tabular}

paracellular route. In vivo studies are required to fully determine the role of candidalysin in gut infections.

\section{Macrophages, Dendritic Cells, and Candidalysin}

Candida albicans forms hyphae once phagocytosed by macrophages, which results in inflammasome activation, cell lysis, and escape. Inflammasome activation requires a priming step and an inflammasome-activating step (Latz et al., 2013). In mouse and human primary monocyte-derived macrophages and dendritic cells, candidalysin $(5-50 \mu \mathrm{M})$ was able to provide the signal to activate the NLRP3 inflammasome, resulting in caspase-1-dependent maturation and secretion of IL-1 $\beta$ (Kasper et al., 2018; Rogiers et al., 2019). As such, candidalysin was shown to promote systemic infection in an intravenous murine model of disseminated candidiasis (Swidergall et al., 2019).

\section{Microglial Cells and Candidalysin}

Within the central nervous system, the C-type lectin receptor/Syk adaptor CARD9 facilitates protective antifungal immunity through neutrophil recruitment (Drummond et al., 2015). Candidalysin $(3-20 \mu \mathrm{M})$ was recently shown to induce chemokine (C-X-C motif) ligand-1 (CXCL1) and IL-1 $\beta$ secretion from CARD9 ${ }^{+}$microglial cells in a p38/c-Fos dependent manner, which recruit CXCR2-expressing neutrophils to the brain to control C. albicans infection (Drummond et al., 2019).

\section{PROTEIN TOXINS: MUCORICIN}

Mucormycosis is an often lethal infection in immunocompromised individuals caused by fungi in the order mucorales. Recent research has identified a $17 \mathrm{kDa}$ ricinlike protein toxin called mucoricin [encoded by RLT1 (Ricin-Like Toxin-1)] which plays a critical role in the pathogenicity of Rhizopus delemar hyphae (Soliman et al., 2021). Treatment of primary alveolar epithelial cells with $29.4 \mu \mathrm{M}$ mucoricin in vitro caused significant cellular damage after $3 \mathrm{~h}$, while mice that received an intravenous inoclulation of $5.9 \mu \mathrm{M}$ mucoricin every second day exhibited a $65 \%$ reduction in survival after 5 days compared to controls (Soliman et al., 2021). Histological examination of organs collected from tretaed mice revealed necrosis, haemorrhage and inflitration of immune cells in lung and liver tissue. Notably, RNAi knockdown of mucoricin expression was observed to attenuate the pathogenicity of Rhizopus delemar in vivo. Mucoricin uses N-glycosylase activity to inhibit protein synthesis, a process which is followed by RNA depurination (Soliman et al., 2021). Intruigingly, orthologues of RLT1 have been identified in other fungi and bacteria (Soliman et al., 2021), suggesting that mucoricin-like proteins may be more widespread in nature. The modulation of host immune responses by mucoricin is summarised in Figure 2.

\section{CONCLUSION}

The biological impact of mycotoxins, peptide and protein toxins on health is significant. Gliotoxin, aflatoxins and candidalysin have been detected in patients with active fungal infections and in experimental models of disease. Furthermore, toxins which are not associated with active infection per se can nevertheless be acquired by ingestion, which can cause acute toxicosis. A common theme that emerges from experimental investigations is the breakdown of mucosal barriers, induction of cell death and the suppression of immune cell function in response to toxin exposure, which may increase host susceptibility to microbial infection. The numerous influences exerted by fungal toxins on host immune defence are summarised in Table 1. While the majority of in vitro mycotoxin studies and those performed in animal models in vivo use a range of toxin concentrations in which specific biological responses are observed, more work is required to establish the relevance of such concentration ranges in the context of acute toxicity and low-level chronic exposure in humans. Further research will undoubtedly increase our understanding of the influences exerted by fungal toxins on health and disease.

\section{AUTHOR CONTRIBUTIONS}

RB wrote the initial draft. EP created figures and figure legends. All authors contributed to manuscript editing. 


\section{FUNDING}

This work was supported by grants from the Wellcome Trust (214229_Z_18_Z), Biotechnology \& Biological Sciences Research Council (BB/N014677/1), National Institutes of

\section{REFERENCES}

Abarca, M. L., Bragulat, M. R., Castella, G., and Cabanes, F. J. (1994). Ochratoxin a production by strains of Aspergillus niger var. niger. Appl. Environ. Microbiol. 60, 2650-2652. doi: 10.1128/aem.60.7.2650-2652.1994

Abid-Essefi, S., Baudrimont, I., Hassen, W., Ouanes, Z., Mobio, T. A., Anane, R., et al. (2003). DNA fragmentation, apoptosis and cell cycle arrest induced by zearalenone in cultured DOK, vero and caco- 2 cells: prevention by Vitamin E. Toxicology 192, 237-248. doi: 10.1016/S0300-483X(03)00329-9

Abid-Essefi, S., Ouanes, Z., Hassen, W., Baudrimont, I., Creppy, E., and Bacha, H. (2004). Cytotoxicity, inhibition of DNA and protein syntheses and oxidative damage in cultured cells exposed to Zearalenone. Toxicol. Vitro 18, 467-474. doi: 10.1016/j.tiv.2003.12.011

Ali, S., Malik, A., Shahid, M., and Bhargava, R. (2013). Pulmonary aspergillosis and aflatoxins in chronic lung diseases. Mycopathologia 176, 287-294. doi: 10.1007/s11046-013-9690-8

Allen, S. J., Wild, C. P., Wheeler, J. G., Riley, E. M., Montesano, R., Bennett, S., et al. (1992). Aflatoxin exposure, malaria and hepatitis B infection in rural gambian children. Trans. R. Soc. Trop. Med. Hygiene 86, 426-430. doi: 10.1016/00359203(92)90253-9

Allert, S., Förster, T. M., Svensson, C. M., Richardson, J. P., Pawlik, T., Hebecker B., et al. (2018). Candida albicans-induced epithelial damage mediates translocation through intestinal barriers. MBio 9, e915-e918. doi: 10.1128/ mBio.00915-18

Almyroudis, N. G., Grimm, M. J., Davidson, B. A., Röhm, M., Urban, C. F., and Segal, B. H. (2013). NETosis and NADPH Oxidase: at the intersection of host defense, inflammation, and injury. Front. Immunol. 4:45. doi: 10.3389/fimmu. 2013.00045

Alshannaq, A., and Yu, J. H. (2017). Occurrence, toxicity, and analysis of major mycotoxins in food. Int. J. Environ. Res. Public Health 14:632. doi: 10.3390/ ijerph14060632

An, Y., Shi, X., Tang, X., Wang, Y., Shen, F., Zhang, Q., et al. (2017). Aflatoxin B1 Induces reactive oxygen species-mediated autophagy and extracellular trap formation in macrophages. Front. Cell. Infect. Microbiol. 7:53. doi: 10.3389/ fcimb.2017.00053

Assunção, R., Alvito, P., Kleiveland, C. R., and Lea, T. E. (2016). Characterization of In vitro effects of patulin on intestinal epithelial and immune cells. Toxicol. Lett. 251, 47-56. doi: 10.1016/j.toxlet.2016.04.007

Aydin, M., Aydin, S., Bacanli, M., and Başaran, N. (2015). Aflatoxin levels in chronic hepatitis B patients with cirrhosis or hepatocellular carcinoma in balikesir, Turkey. J. Viral Hepatitis 22, 926-935. doi: 10.1111/jvh.12410

Bahrami, R., Shahbazi, Y., and Nikousefat, Z. (2016). Aflatoxin M1 in milk and traditional dairy products from west part of iran: occurrence and seasonal variation with an emphasis on risk assessment of human exposure. Food Control 62, 250-256. doi: 10.1016/j.foodcont.2015.10.039

Barhoumi, R., and Burghardt, R. C. (1996). Kinetic analysis of the chronology of patulin-and gossypol-lnduced cytotoxicity in vitro. Fundimental Appl. Toxicol. 30, 290-297.

Bayman, P., Baker, J. L., Doster, M. A., Michailides, T. J., and Mahoney, N. E. (2002). Ochratoxin production by the Aspergillus ochraceus group and Aspergillus alliaceus. Appl. Environ. Microbiol. 68, 2326-2329. doi: 10.1128/ AEM.68.5.2326-2329.2002

Benkerroum, N. (2020a). Aflatoxins: producing-molds, structure, health issues and incidence in southeast Asian and Sub-saharan African countries. Int. J. Environ. Res. Public Health 17:1215. doi: 10.3390/ijerph17041215

Benkerroum, N. (2020b). Chronic and acute toxicities of aflatoxins: mechanisms of action. Int. J. Environ. Res. Public Health 17, 1-28. doi: 10.3390/ijerph17020423

Berthiller, F., Crews, C., Dall'Asta, C., De Saeger, S., Haesaert, G., Karlovsky, P., et al. (2013). Masked mycotoxins: a review. Mol. Nutr. Food Res. 57, 165-186. doi: $10.1002 / \mathrm{mnfr} .201100764$
Health (R37-DE022550), the NIH Research at Guys and St. Thomas's NHS Foundation Trust and the King's College London Biomedical Research Centre (IS-BRC-1215-20006), and a Faculty of Dentistry, Oral \& Craniofacial Sciences (FoDOCS) Ph.D. studentship.

Betbeder, A. M., Creppy, E. E., and El May, M. (1995). Ochratoxin a in human blood in relation to nephropathy in tunisia. Hum. Exp. Toxicol. 14, 609-614. doi: 10.1177/096032719501400710

Bianco, G., Russo, R., Marzocco, S., Velotto, S., Autore, G., and Severino, L. (2012). Modulation of macrophage activity by aflatoxins B1 and B2 and their metabolites aflatoxins M1 and M2. Toxicon 59, 644-650. doi: 10.1016/j.toxicon. 2012.02.010

Bishu, S., Hernández-Santos, N., Simpson-Abelson, M. R., Huppler, A. R., Conti, H. R., Ghilardi, N., et al. (2014). The adaptor CARD9 is required for adaptive but not innate immunity to oral mucosal Candida albicans infections. Infect. Immun. 82, 1173-1180. doi: 10.1128/IAI.01335-13

Blount, W. P. (1961). Turkey 'X' disease. Journal of British Turkey Federation, 9, 52-61.

Bogdan, C., Röllinghoff, M., and Diefenbach, A. (2000). The role of nitric oxide in innate immunity. Immunol. Rev. 173, 17-26. doi: 10.1034/j.1600-065X.2000. 917307.x

Bok, J. W., Balajee, S. A., Marr, K. A., Andes, D., Nielsen, K. F., Frisvad, J. C., et al. (2005). LaeA, a regulator of morphogenetic fungal virulence factors. Eukaryotic Cell 4, 1574-1582. doi: 10.1128/EC.4.9.1574-1582.2005

Bok, J. W., Chung, D., Balajee, S. A., Marr, K. A., Andes, D., Nielsen, K. F., et al. (2006). GliZ, a transcriptional regulator of gliotoxin biosynthesis, contributes to aspergillus fumigatus virulence. Infect. Immun. 74, 6761-6768. doi: 10.1128/ IAI.00780-06

Bony, S., Olivier-Loiseau, L., Carcelen, M., and Devaux, A. (2007). Genotoxic potential associated with low levels of the fusarium mycotoxins nivalenol and fusarenon $\mathrm{X}$ in a human intestinal cell line. Toxicol. Vitro 21, 457-465. doi: 10.1016/j.tiv.2006.10.014

Boorman, G. A., McDonald, M. R., Imoto, S., and Persing, R. (1992). Renal lesions induced by ochratoxin a exposure in the F344 rat. Toxicol. Pathol. 20, 236-245. doi: $10.1177 / 019262339202000210$

Bourdiol, D., Escoula, L., and Salvayre, R. (1990). Effect of patulin on microbicidal activity of mouse peritoneal macrophages. Food Chem. Toxicol. 28, 29-33. doi: 10.1016/0278-6915(90)90132-7

Brennan, K. M., Oh, S. Y., Yiannikouris, A., Graugnard, D. E., and Karrow, N. A. (2017). Differential gene expression analysis of bovine macrophages after exposure to the Penicillium mycotoxins citrinin and/or ochratoxin a. Toxins (Basel) 9:366. doi: 10.3390/toxins9110366

Brown, G. D., Denning, D. W., Gow, N. A. R., Levitz, S. M., Netea, M. G., and White, T. C. (2012). Hidden killers: human fungal infections. Sci. Transl. Med. 4:165rv13. doi: 10.1126/scitranslmed.3004404

Cabañes, F. J., Bragulat, M. R., and Castellá, G. (2010). Ochratoxin a producing species in the genus Penicillium. Toxins 2, 1111-1120. doi: 10.3390/ toxins 2051111

Caloni, F., Cortinovis, C., Pizzo, F., and De Angelis, I. (2012). Transport of aflatoxin M1 in human intestinal Caco-2/TC7 cells. Front. Pharmacol. 3:111. doi: 10.3389/fphar.2012.00111

Cano, P. M., Seeboth, J., Meurens, F., Cognie, J., Abrami, R. I, Oswald, P., et al. (2013). Deoxynivalenol as a new factor in the persistence of intestinal inflammatory diseases: an emerging hypothesis through possible modulation of Th17-mediated response. PLoS One 8:e53647. doi: 10.1371/journal.pone. 0053647

Chai, C. L. L., and Waring, P. (2000). Redox sensitive epidithiodioxopiperazines in biological mechanisms of Toxicity. Redox Rep. 5, 257-264. doi: 10.1179/ 135100000101535799

Chatterjee, D., Mukherjee, S. K., and Dey, A. (1995). Nuclear disintegration in chicken peritoneal macrophages exposed to fumonisin B1 from Indian Maize. Lett. Appl. Microbiol. 20, 184-185. doi: 10.1111/j.1472-765X.1995.tb0 0422.x

Chikina, A. S., Nadalin, F., Maurin, M., San-Roman, M., Thomas-Bonafos, T., Li, X. V., et al. (2020). Macrophages maintain epithelium integrity by limiting 
fungal product absorption. Cell 183, 411-428.e16. doi: 10.1016/j.cell.2020. 08.048

Choi, H. J., Yang, H., Park, S. H., and Moon, Y. (2009). HuR/ELAVL1 RNA binding protein modulates interleukin- 8 induction by muco-active ribotoxin deoxynivalenol. Toxicol. Appl. Pharmacol. 240, 46-54. doi: 10.1016/j.taap.2009. 06.023

Chung, Y. J., Zhou, H. R., and Pestka, J. J. (2003). Transcriptional and posttranscriptional roles for P38 mitogen-activated protein kinase in upregulation of TNF- $\alpha$ expression by deoxynivalenol (Vomitoxin). Toxicol. Appl. Pharmacol. 193, 188-201. doi: 10.1016/S0041-008X(03)00299-0

Coméra, C., André, K., Laffitte, J., Collet, X., Galtier, P., and Maridonneau-Parini, I. (2007). Gliotoxin from Aspergillus fumigatus affects phagocytosis and the organization of the actin cytoskeleton by distinct signalling pathways in human neutrophils. Microbes Infect. 9, 47-54. doi: 10.1016/j.micinf.2006.10.009

Cowburn, A. S., Deighton, J., Walmsley, S. R., and Chilvers, E. R. (2004). The survival effect of TNF- $\alpha$ in human neutrophils is mediated via NF-KBdependent IL-8 release. Eur. J. Immunol. 34, 1733-1743. doi: 10.1002/eji. 200425091

Cusumano, V., Costa, G. B., and Seminara, S. (1990). Effect of aflatoxins on rat peritoneal macrophages downloaded from. Appl. Environ. Microbiol. 56, 3482-3484.

Cusumano, V., Rossano, F., Merendino, R. A., Arena, A., Costa, G. B., Mancuso, G., et al. (1996). Immunobiological activities of mould products: functional impairment of human monocytes exposed to aflatoxin B1. Res. Microbiol. 147, 385-391. doi: 10.1016/0923-2508(96)84713-9

Devriendt, B., Gallois, M., Verdonck, F., Wache, Y., Bimczok, D. I, Oswald, P., et al. (2010). "The food contaminant fumonisin B1 reduces the maturation of porcine CD11R1+ intestinal dendritic cells, resulting in a reduced efficiency of oral immunisation and a prolonged intestinal ETEC infection," in Proceedings of the Dendritic Cells in Fundamental and Clinical Immunology, 11th International Symposium, Abstracts, (Lugano).

Dhuley, J. N. (1997). Effect of some indian herbs on macrophage functions in ochratoxin a treated mice. J. Ethnopharmacol. 58, 15-20. doi: 10.1016/S03788741(97)00072-X

Diallo, M. S., Sylla, A., Sidibé, K., Sylla, B. S., Trepo, C. R., and Wild, C. P. (1995). Prevalence of exposure to aflatoxin and hepatitis B and C Viruses in Guinea, West Africa. Nat. Toxins 3, 6-9. doi: 10.1002/nt.2620030103

Drummond, R. A., Collar, A. L., Swamydas, M., Rodriguez, C. A., Lim, J. K., Mendez, L. M., et al. (2015). CARD9-dependent neutrophil recruitment protects against fungal invasion of the central nervous system. PLoS Pathogens 11:e1005293. doi: 10.1371/journal.ppat.1005293

Drummond, R. A., Swamydas, M., Oikonomou, V., Zhai, B. I, Dambuza, M., Schaefer, B. C., et al. (2019). CARD9 + microglia promote antifungal immunity via IL-1 $\beta$ - and CXCL1-mediated neutrophil recruitment. Nat. Immunol. 20, 559-570. doi: 10.1038/s41590-019-0377-2

EFSA (2013). Scientific opinion on the hazard assessment of endocrine disruptors: scientific criteria for identification of endocrine disruptors and appropriateness of existing test methods for assessing effects mediated by these substances on human health and the environment1. EFSA J. 11:3132. doi: 10.2903/j.efsa.2013. 3132

Eskola, M., Kos, G., Elliott, C. T., Hajšlová, J., Mayar, S., and Krska, R. (2020). Worldwide contamination of food-crops with mycotoxins: validity of the Widely Cited 'FAO Estimate' of 25\%. Crit. Rev. Food Sci. Nutr. 60, 2773-2789. doi: $10.1080 / 10408398.2019 .1658570$

Fan, W., Lv, Y., Ren, S., Shao, M., Shen, T., Huang, K., et al. (2018). Zearalenone (ZEA)-induced intestinal inflammation is mediated by the NLRP3 inflammasome. Chemosphere 190, 272-279. doi: 10.1016/j.chemosphere.2017. 09.145

Fan, W., Shen, T., Ding, Q., Lv, Y., Li, L., Huang, K., et al. (2017). Zearalenone induces ROS-mediated mitochondrial damage in porcine IPEC-J2 cells. J. Biochem. Mol. Toxicol. 31:e21944. doi: 10.1002/jbt.21944

Ferrante, M. C., Bilancione, M., Raso, G. M., Esposito, E., Iacono, A., Zaccaroni, A., et al. (2006). Expression of COX-2 and Hsp72 in peritoneal macrophages after an acute ochratoxin a treatment in mice. Life Sci. 79, 1242-1247. doi: 10.1016/j.lfs.2006.03.031

Ferri, F., Brera, C., De Santis, B., Fedrizzi, G., Bacci, T., Bedogni, L., et al. (2017). Survey on urinary levels of aflatoxins in professionally exposed workers. Toxins 9:117. doi: 10.3390/toxins9040117
Fitzpatrick, L. R., Wang, J., and Le, T. (2000). In Vitro and In Vivo Effects of gliotoxin, a fungal metabolite: efficacy against dextran sodium sulfate-induced colitis in rats. Dig. Dis. Sci. 45, 2327-2336. doi: 10.1023/A:1005630723111

Forsyth, D. M., Yoshizawa, T., Morooka, N., and Tuite, J. (1977). Emetic and refusal activity of deoxynivalenol to swine. Appl. Environ. Microbiol. 34, 547-552. doi: 10.1128/aem.34.5.547-552.1977

François, S., Benna, J. E., Dang, P. M. C., Pedruzzi, E., Gougerot-Pocidalo, M. A., and Elbim, C. (2005). Inhibition of neutrophil apoptosis by TLR agonists in whole blood: involvement of the phosphoinositide 3-kinase/Akt and NF-KB signaling pathways, leading to increased levels of Mcl-1, A1, and phosphorylated bad. J. Immunol. 174, 3633-3642. doi: 10.4049/jimmunol.174. 6.3633

Friend, D. W., Trenholm, H. L., Elliot, J. I., Hartin, K. E., and Thompson, B. K. (1982). Effect of feeding vomitoxin-contaminated wheat to pigs. Can. J. Anim. Sci. 62, 1211-1222. doi: 10.4141/cjas82-141

Frisvad, J. C. (2018). A critical review of producers of small lactone mycotoxins: patulin, penicillic acid and moniliformin. World Mycotoxin J. 11, 73-100. doi: 10.3920/WMJ2017.2294

Fujihara, S., Ward, C., Dransfield, I., Hay, R. T., Uings, J. I, Hayes, B., et al. (2002). Inhibition of nuclear factor-KB activation un-masks the ability of TNF- $\alpha$ to induce human eosinophil apoptosis. Eur. J. Immunol. 32, 457-466.

Gallo, A., Ferrara, M., and Perrone, G. (2013). Phylogenetic study of polyketide synthases and nonribosomal peptide synthetases involved in the biosynthesis of mycotoxins. Toxins 5, 717-742. doi: 10.3390/toxins5040717

Gao, Y., Li, S., Wang, J., Luo, C., Zhao, S., and Zheng, N. (2017). Modulation of intestinal epithelial permeability in differentiated caco-2 cells exposed to aflatoxin M1 and ochratoxin a individually or collectively. Toxins 10:13. doi: $10.3390 /$ toxins 10010013

Gao, Y., Meng, L., Liu, H., Wang, J., and Zheng, N. (2020a). The compromised intestinal barrier induced by mycotoxins. Toxins 12:619. doi: 10.3390/ toxins 12100619

Gao, Y., Ye, Q., Bao, X., Huang, X., Wang, J., and Zheng, N. (2020b). Transcriptomic and proteomic profiling reveals the intestinal immunotoxicity induced by aflatoxin M1 and ochratoxin A. Toxicon 180, 49-61. doi: 10.1016/j. toxicon.2020.03.008

Gauthier, T., Waché, Y., Laffitte, J., Taranu, I., Saeedikouzehkonani, N., Mori, Y., et al. (2013). Deoxynivalenol impairs the immune functions of neutrophils. Mol. Nutr. Food Res. 57, 1026-1036. doi: 10.1002/mnfr.201200755

Geiser, D. M., Dorner, J. W., Horn, B. W., and Taylor, J. W. (2000). The phylogenetics of mycotoxin and sclerotium production in Aspergillus flavus and Aspergillus oryzae. Fungal Genet. Biol. 31, 169-179. doi: 10.1006/fgbi.2000.1215

Geissler, A., Haun, F., Frank, D. O., Wieland, K., Simon, M. M., Idzko, M., et al. (2013). Apoptosis induced by the fungal pathogen gliotoxin requires a triple phosphorylation of bim by JNK. Cell Death Differ. 20, 1317-1329. doi: 10.1038/ cdd.2013.78

Ghédira-Chékir, L., Maaroufi, K., Creppy, E. E., and Bacha, H. (1999). Cytotoxic and genotoxic effects of zearalenone: prevention by Vitamin E. J. Toxicol. Toxin Rev. 18, 355-368. doi: 10.3109/15569549909009263

Goto, T., Wicklow, D. T., and Ito, Y. (1996). Aflatoxin and cyclopiazonic acid production by a sclerotium-producing Aspergillus Tamarii strain. Appl. Environ. Microbiol. 62, 4036-4038. doi: 10.1128/aem.62.11.4036-4038.1996

Gratz, S. W. (2017). Do plant-bound masked mycotoxins contribute to toxicity? Toxins 9:85. doi: 10.3390/toxins 9030085

Gratz, S. W., Dinesh, R., Yoshinari, T., Holtrop, G., Richardson, A. J., Duncan, G., et al. (2017). Masked trichothecene and zearalenone mycotoxins withstand digestion and absorption in the upper GI tract but are efficiently hydrolyzed by human gut microbiota In Vitro. Mol. Nutr. Food Res. 61, 680-690. doi: $10.1002 / \mathrm{mnfr} .201600680$

Grenier, B., Loureiro-Bracarense, A. P., Lucioli, J., Pacheco, G. D., Cossalter, A. M., Moll, W. D., et al. (2011). Individual and combined effects of subclinical doses of deoxynivalenol and fumonisins in piglets. Mol. Nutr. Food Res. 55, 761-771. doi: $10.1002 / \mathrm{mnfr} .201000402$

Guerra-Moreno, A., and Hanna, J. (2017). Induction of proteotoxic stress by the mycotoxin patulin. Toxicol. Lett. 276, 85-91. doi: 10.1016/j.toxlet.2017.05.015

Guerre, P. (2020). Mycotoxin and gut microbiota interactions. Toxins 12:769. doi: 10.3390/toxins12120769

He, K., Pan, X., Zhou, H. R., and Pestka, J. J. (2013). Modulation of inflammatory gene expression by the ribotoxin deoxynivalenol involves coordinate regulation 
of the transcriptome and translatome. Toxicol. Sci. 131, 153-163. doi: 10.1093/ toxsci/kfs266

Hestbjerg, H., Nielsen, K. F., Thrane, U., and Elmholt, S. (2002). Production of Trichothecenes and other secondary metabolites by Fusarium culmorum and Fusarium equiseti on Common laboratory media and a soil organic matter agar: an ecological interpretation. J. Agric. Food Chem. 50, 7593-7599. doi: $10.1021 /$ jf020432o

Ho, J., Wickramasinghe, D. N., Nikou, S. A., Hube, B., Richardson, J. P., and Naglik, J. R. (2020). Candidalysin is a potent trigger of alarmin and antimicrobial peptide release in epithelial cells. Cells 9:699. doi: 10.3390/cells9030699

Ho, J., Yang, X., Nikou, S. A., Kichik, N., Donkin, A., Ponde, N. O., et al. (2019). Candidalysin activates innate epithelial immune responses via epidermal growth factor receptor. Nat. Commun. 10:2297. doi: 10.1038/s41467-01909915-2

Hou, L., Gan, F., Zhou, X., Zhou, Y., Qian, G., Liu, Z., et al. (2018). Immunotoxicity of ochratoxin a and aflatoxin B1 in combination is associated with the nuclear factor kappa B signaling pathway in 3D4/21?cells. Chemosphere 199, 718-727. doi: 10.1016/j.chemosphere.2018.02.009

Hymery, N., Léon, K., Carpentier, F. G., Jung, J. L., and Parent-Massin, D. (2009). T-2 toxin inhibits the differentiation of human monocytes into dendritic cells and macrophages. Toxicol. Vitro 23, 509-519. doi: 10.1016/j.tiv.2009.01.003

Hymery, N., Sibiril, Y., and Parent-Massin, D. (2006). In vitro effects of trichothecenes on human dendritic cells. Toxicol. Vitro 20, 899-909. doi: 10 1016/j.tiv.2006.01.015

Islam, Z., Gray, J. S., and Pestka, J. J. (2006). P38 mitogen-activated protein kinase mediates IL- 8 induction by the ribotoxin deoxynivalenol in human monocytes. Toxicol. Appl. Pharmacol. 213, 235-244. doi: 10.1016/j.taap.2005.11.001

Iverson, F., Armstrong, C., Nera, E., Truelove, J., Fernie, S., Scott, P., et al. (1995). Chronic feeding study of deoxynivalenol in B6C3F1 male and female mice. Teratog. Carcinog. Mutagen. 15, 283-306. doi: 10.1002/tcm.1770150606

Jahreis, S., Kuhn, S., Madaj, A. M., Bauer, M. and Polte, T. (2017). Mold metabolites drive rheumatoid arthritis in mice via promotion of IFN-gamma- and IL-17producing T cells. Food Chem. Toxicol. 109, 405-413. doi: 10.1016/j.fct.2017.09. 027

Jia, X., Chen, F., Pan, W., Yu, R., Tian, S., Han, G., et al. (2014). Gliotoxin promotes aspergillus fumigatus internalization into type II human pneumocyte A549 cells by inducing host phospholipase D activation. Microbes Infect. 16, 491-501. doi: 10.1016/j.micinf.2014.03.001

Jiang, Y., Jolly, P. E., Ellis, W. O., Wang, J. S., Phillips, T. D., and Williams, J. H. (2005). Aflatoxin B1 albumin adduct levels and cellular immune status in ghanaians. Int. Immunol. 17, 807-814. doi: 10.1093/intimm/dxh262

Jin, Y., Chen, Q., Luo, S., He, L., Fan, R., Zhang, S., et al. (2021). Dual near-infrared fluorescence-based lateral flow immunosensor for the detection of zearalenone and deoxynivalenol in maize. Food Chem. 336:127718. doi: 10.1016/j.foodchem. 2020.127718

Johannessen, L. N., Nilsen, A. M., and Løvik, M. (2005). The mycotoxins citrinin and gliotoxin differentially affect production of the pro-inflammatory cytokines tumour necrosis factor- $\alpha$ and interleukin-6, and the anti-inflammatory cytokine interleukin-10. Clin. Exp. Allergy 35, 782-789. doi: 10.1111/j.13652222.2005.02249.x

Kasper, L., König, A., Koenig, P. A., Gresnigt, M. S., Westman, J., Drummond, R. A., et al. (2018). the fungal peptide toxin Candidalysin activates the NLRP3 inflammasome and causes cytolysis in mononuclear phagocytes. Nat. Commun. 9:4260. doi: 10.1038/s41467-018-06607-1

Katsuyama, A., Konno, T., Shimoyama, S., and Kikuchi, H. (2014). The mycotoxin patulin decreases expression of density-enhanced phosphatase-1 by downregulating PPAR $\gamma$ in human colon cancer cells. Tohoku J. Exp. Med. 233, 265-274. doi: 10.1620/tjem.233.265

Kawauchiya, T., Takumi, R., Kudo, Y., Takamori, A., Sasagawa, T., Takahashi, K., et al. (2011). Correlation between the destruction of tight junction by patulin treatment and increase of phosphorylation of ZO-1 in Caco-2 human colon cancer cells. Toxicol. Lett. 205, 196-202. doi: 10.1016/j.toxlet.2011.06.006

Kikuchi, H., Miyagawa, Y., Sahashi, Y., Inatomi, S., Haganuma, A., Nakahata, N., et al. (2004). Novel Spirocyclic Trichothecanes, Spirotenuipesine A and B, isolated from Entomopathogenic Fungus, Paecilomyces tenuipes. J. Org. Chem. 69, 352-356. doi: 10.1021/jo035137x

Kim, Y. T., Lee, Y. R., Jin, J., Han, K. H., Kim, H., Kim, J. C., et al. (2005). Two different polyketide synthase genes are required for synthesis of Zearalenone in
Gibberella zeae. Mol. Microbiol. 58, 1102-1113. doi: 10.1111/j.1365-2958.2005. 04884.x

Klich, M., Mullaney, E., Daly, C., and Cary, J. W. (2000). Molecular and physiological aspects of aflatoxin and sterigmatocystin biosynthesis by Aspergillus tamarii and A. ochraceoroseus. Appl. Microbiol. Biotechnol. 53, 605-609. doi: 10.1007/s002530051664

Kouadio, J. H., Mobio, T. A., Baudrimont, I., Moukha, S., Dano, S. D., and Creppy, E. E. (2005). Comparative study of cytotoxicity and oxidative stress induced by Deoxynivalenol, Zearalenone or Fumonisin B1 in human intestinal cell line Caco-2. Toxicology 213, 56-65. doi: 10.1016/j.tox.2005.05.010

Kupfahl, C., Heinekamp, T., Geginat, G., Ruppert, T., Härtl, A., Hof, H., et al. (2006). Deletion of the GliP gene of Aspergillus fumigatus results in loss of gliotoxin production but has no effect on virulence of the fungus in a low-dose mouse infection model. Mol. Microbiol. 62, 292-302. doi: 10.1111/j.1365-2958. 2006.05373.x

Kupski, L., Freitas, M., Ribeiro, D., Furlong, E. B., and Fernandes, E. (2016). Ochratoxin A activates neutrophils and kills these cells through necrosis, an effect eliminated through its conversion into Ochratoxin $\alpha$. Toxicology 368-369. doi: 10.1016/j.tox.2016.09.001

Latz, E., Xiao, T. S., and Stutz, A. (2013). Activation and regulation of the inflammasomes. Nat. Rev. Immunol. 13, 397-411. doi: 10.1038/nri3452

Levin, R., Grinstein, S., and Schlam, D. (2015). Phosphoinositides in phagocytosis and macropinocytosis. Biochim. Biophys. Acta Mol. Cell Biol. Lipids 1851, 805-823. doi: 10.1016/j.bbalip.2014.09.005

Lewis, R. E., Wiederhold, N. P., Chi, J., Han, X. Y., Komanduri, K. V., Kontoyiannis, D. P., et al. (2005). Detection of gliotoxin in experimental and human aspergillosis. Infect. Immun. 73, 635-637. doi: 10.1128/IAI.73.1.635-637.2005

Li, B., Chen, Y., Zong, Y., Shang, Y., Zhang, Z., Xu, X., et al. (2019). Dissection of patulin biosynthesis, spatial control and regulation mechanism in Penicillium expansum. Environ. Microbiol. 21, 1124-1139. doi: 10.1111/1462-2920.14542

Li, D., Han, J., Guo, X., Qu, C., Yu, F., and Wu, X. (2016). The effects of T-2 toxin on the prevalence and development of Kashin-Beck disease in China: a meta-analysis and systematic review. Toxicol. Res. 5, 731-751. doi: 10.1039/ c5tx00377f

Li, P., Su, R., Yin, R., Lai, D., Wang, M., Liu, Y., et al. (2020). Detoxification of mycotoxins through biotransformation. Toxins 12:121. doi: 10.3390/ toxins 12020121

Liu, B. H., Yu, F. Y., Chan, M. H., and Yang, Y. L. (2002). The effects of mycotoxins, fumonisin B1 and aflatoxin B1, on primary swine alveolar macrophages. Toxicol. Appl. Pharmacol. 180, 197-204. doi: 10.1006/taap.2002.9406

Loftus, J., Kijanka, G., O’Kennedy, R., and Loscher, C. E. (2016). Patulin, deoxynivalenol, zearalenone and T-2 toxin affect viability and modulate cytokine secretion in J774A.1 murine macrophages. Int. J. Chem. 8:22. doi: $10.5539 /$ ijc.v8n2p22

Luft, P., Oostingh, G. J., Gruijthuijsen, Y., Horejs-Hoeck, J., Lehmann, I., and Duschl, A. (2008). Patulin influences the expression of Th1/Th2 cytokines by activated peripheral blood mononuclear cells and $\mathrm{T}$ cells through depletion of intracellular glutathione. Environ. Toxicol. 23, 84-95. doi: 10.1002/tox.20309

Luo, X. (1994). "Food poisoning caused by fusarium toxins," in Proceedings of The 2nd Asian Conference on Food Safety, (Bangkok: International Life Science Institute).

Maaroufi, K., Achour, A., Betbeder, A. M., Hammami, M., Ellouz, F., Creppy, E. E. et al. (1995). Foodstuffs and human blood contamination by the mycotoxin ochratoxin A: correlation with chronic interstitial nephropathy in Tunisia. Arch. Toxicol. 69, 552-558. doi: 10.1007/s002040050211

Malik, A., Ali, S., Shahid, M., and Bhargava, R. (2014). Occupational exposure to Aspergillus and aflatoxins among food-grain workers in India. Int. J. Occup. Environ. Health 20, 189-193. doi: 10.1179/2049396714Y.0000000055

Marijanovic, D. R., Holt, P., Norred, W. P., Bacon, C. W., Voss, K. A., Stancel, P. C., et al. (1991). Immunosuppressive effects of Fusarium moniliforme corn cultures in chickens. Poult. Sci. 70, 1895-1901. doi: 10.3382/ps.0701895

Marin, D. E., Pistol, G. C., Gras, M. A., Palade, M. L., and Taranu, I. (2017). Comparative effect of ochratoxin a on inflammation and oxidative stress parameters in gut and kidney of piglets. Regul. Toxicol. Pharmacol. 89, 224-231. doi: 10.1016/j.yrtph.2017.07.031

Marin, D. E., Taranu, I., Burlacu, R., and Tudor, D. S. (2010). Effects of zearalenone and its derivatives on the innate immune response of Swine. Toxicon 56, 956-963. doi: 10.1016/j.toxicon.2010.06.020 
Marzocco, S., Russo, R., Bianco, G., Autore, G., and Severino, L. (2009). Proapoptotic effects of nivalenol and deoxynivalenol trichothecenes in J774A.1 murine macrophages. Toxicol. Lett. 189, 21-26. doi: 10.1016/j.toxlet.2009. 04.024

McCormick, S. P., Stanley, A. M., Stover, N. A., and Alexander, N. J. (2011). Trichothecenes: from simple to complex mycotoxins. Toxins 3, 802-814. doi: 10.3390/toxins3070802

McLaughlin, J., Padfield, P. J., Burt, J. P., and O’Neill, C. A. (2004). Ochratoxin a increases permeability through tight junctions by removal of specific claudin isoforms. Am. J. Physiol. Cell Physiol. 287, C1412-C1417. doi: 10.1152/ajpcell. 00007.2004

Mehrzad, J., Devriendt, B., Baert, K., and Cox, E. (2014). Aflatoxin B1 Interferes with the antigen-presenting capacity of porcine dendritic cells. Toxicol. Vitro 28, 531-537. doi: 10.1016/j.tiv.2013.11.015

Mehrzad, J., Fazel, F., Pouyamehr, N., Hosseinkhani, S., and Dehghani, H. (2020). Naturally occurring level of aflatoxin b1 injures human, canine and bovine leukocytes through ATP depletion and caspase activation. Int. J. Toxicol. 39, 30-38. doi: 10.1177/1091581819892613

Mehrzad, J., Klein, G., Kamphues, J., Wolf, P., Grabowski, N., and Schuberth, H. J. (2011). In vitro effects of very low levels of aflatoxin B1 on free radicals production and bactericidal activity of bovine blood neutrophils. Vet. Immunol. Immunopathol. 141, 16-25. doi: 10.1016/j.vetimm.2011.01.010

Mekuria, A. N., Routledge, M. N., Gong, Y. Y., and Sisay, M. (2020). Aflatoxins as a risk factor for liver cirrhosis: a systematic review and meta-analysis. BMC Pharmacol. Toxicol. 21:39. doi: 10.1186/s40360-020-00420-7

Mirocha, C. J., Pathre, S. V., and Robison, T. S. (1981). Comparative metabolism of zearalenone and transmission into bovine milk. Food Cosmet. Toxicol. 19, 25-30. doi: 10.1016/0015-6264(81)90299-6

Mohammadi, A., Mehrzad, J., Mahmoudi, M., and Schneider, M. (2014). Environmentally relevant level of aflatoxin B1 dysregulates human dendritic cells through signaling on key toll-like receptors. Int. J. Toxicol. 33, 175-186. doi: $10.1177 / 1091581814526890$

Moon, E. Y., and Pyo, S. (2000). Aflatoxin B1 inhibits CD14-mediated nitric oxide production in murine peritoneal macrophages. Int. J. Immunopharmacol. 22, 237-246. doi: 10.1016/S0192-0561(99)00081-8

Moon, Y., and Pestka, J. J. (2002). Vomitoxin-induced cyclooxygenase-2 gene expression in macrophages mediated by activation of ERK and P38 but Not JNK mitogen-activated protein kinases. Toxicol. Sci. 69, 373-382. doi: 10.1093/ toxsci/69.2.373

Moyes, D. L., Runglall, M., Murciano, C., Shen, C., Nayar, D., Thavaraj, S., et al. (2010). A biphasic innate immune MAPK response discriminates between the yeast and hyphal forms of candida albicans in epithelial cells. Cell Host Microbe 8, 225-235. doi: 10.1016/j.chom.2010.08.002

Moyes, D. L., Wilson, D., Richardson, J. P., Mogavero, S., Tang, S. X., Wernecke, J., et al. (2016). Candidalysin is a fungal peptide toxin critical for mucosal infection. Nature 532, 64-68. doi: 10.1038/nature17625

Mullbacher, A., and Eichner, R. D. (1984). Immunosuppression in vitro by a metabolite of a human pathogenic fungus. Proc. Natl. Acad. Sci. U.S.A. 81, 3835-3837. doi: 10.1073/pnas.81.12.3835

Müller, G., Kielstein, P., Köhler, H., Berndt, A., and Rosner, H. (1995). Studies of the influence of ochratoxin a on immune and defence reactions in the mouse model. Mycoses 38, 85-91. doi: 10.1111/j.1439-0507.1995.tb00013.x

Naglik, J. R., Gaffen, S. L., and Hube, B. (2019). Candidalysin: discovery and function in candida albicans infections. Curr. Opin. Microbiol. 52, 100-109. doi: 10.1016/j.mib.2019.06.002

Newberne, P. M., and Butler, W. H. (1969). Acute and chronic effects of aflatoxin on the liver of domestic and laboratory animals: a review. Cancer Res. 29, 230-250.

Oh, S. Y., Balch, C. G., Cliff, R. L., Sharma, B. S., Boermans, H. J., Swamy, H. V., et al. (2013). Exposure to penicillium mycotoxins alters gene expression of enzymes involved in the epigenetic regulation of bovine macrophages (BoMacs). Mycotoxin Res. 29, 235-243. doi: 10.1007/s12550-013-0174-y

Oh, S. Y., Mead, P. J., Sharma, B. S., Quinton, V. M., Boermans, H. J., Smith, T. K., et al. (2015). Effect of penicillium mycotoxins on the cytokine gene expression, reactive oxygen species production, and phagocytosis of bovine macrophage (BoMacs) function. Toxicol. Vitro 30(1 Pt B), 446-453. doi: 10.1016/j.tiv.2015. 09.017

Orciuolo, E., Stanzani, M., Canestraro, M., Galimberti, S., Carulli, G., Lewis, R., et al. (2007). Effects of Aspergillus fumigatus gliotoxin and methylprednisolone on human neutrophils: implications for the pathogenesis of invasive Aspergillosis. J. Leukocyte Biol. 82, 839-848. doi: 10.1189/jlb.0207090

Özsoy, N., Selmanoğlu, G., Koçkaya, E. A., Gül, N., and Cebesoy, S. (2008). Effect of patulin on the interdigitating dendritic cells (IDCs) of rat thymus. Cell Biochem. Funct. 26, 192-196. doi: 10.1002/cbf.1431

Pahl, H. L., Krauss, B., Schulze-Osthoff, K., Decker, T., Traenckner, E. B., Vogt, M., et al. (1996). The immunosuppressive fungal metabolite gliotoxin specifically inhibits transcription factor NF-KB. J. Exp. Med. 183, 1829-1840. doi: 10.1084/ jem.183.4.1829

Pardo, J., Urban, C., Galvez, E. M., Ekert, P. G., Müller, U., Kwon-Chung, J., et al. (2006). The mitochondrial protein bak is pivotal for gliotoxin-induced apoptosis and a critical host factor of Aspergillus fumigatus virulence in mice. J. Cell Biol. 174, 509-519. doi: 10.1083/jcb.200604044

Payros, D., Ménard, S., Laffitte, J., Neves, M., Tremblay-Franco, M., Luo, S., et al. (2020). The food contaminant, deoxynivalenol, modulates the thelper/treg balance and increases inflammatory bowel diseases. Arch. Toxicol. 94, 31733184. doi: 10.1007/s00204-020-02817-z

Peers, F. G. (1973). Dietary aflatoxins and liver cancer-a population based study in Kenya. Br. J. Cancer 27, 473-484. doi: 10.1038/bjc.1973.60

Pestka, J., and Zhou, H. R. (2006). Toll-like receptor priming sensitizes macrophages to proinflammatory cytokine gene induction by deoxynivalenol and other toxicants. Toxicol. Sci. 92, 445-455. doi: 10.1093/toxsci/kfl012

Peterson, S. W., Ito, Y., Horn, B. W., and Goto, T. (2001). aspergillus bombycis, a new aflatoxigenic species and genetic variation in its sibling species, a. nomius. Mycologia 93, 689-703. doi: 10.2307/3761823

Pierron, A., Alassane-Kpembi, I., and Oswald, I. P. (2016). Impact of mycotoxin on immune response and consequences for pig health. Anim. Nutr. 2, 63-68. doi: 10.1016/j.aninu.2016.03.001

Pinton, P., Braicu, C., Nougayrede, J. P., Laffitte, J., Taranu, I., and Oswald, I. P. (2010). Deoxynivalenol impairs porcine intestinal barrier function and decreases the protein expression of claudin- 4 through a mitogen-activated protein kinase-dependent mechanism. J. Nutr. 140, 1956-1962. doi: 10.3945/ jn.110.123919

Power, M., Sharma, A. K., Lees, K. R., and Smithard, D. G. (2002). Dietary aflatoxin exposure and impaired growth in young children from benin and togo: cross sectional study. Bmj 325, 1089a-1089a. doi: 10.1136/bmj.325.7372.1089/a

Prelusky, D. B., and Trenholm, H. L. (1993). The efficacy of various classes of anti-emetics in preventing deoxynivalenol-induced vomiting in swine. Nat. Toxins 1, 296-302. doi: 10.1002/nt.2620010508

Puel, O., Galtier, P., and Oswald, I. P. (2010). Biosynthesis and toxicological effects of patulin. Toxins 2, 613-631. doi: 10.3390/toxins2040613

Qureshi, M. A., Garlich, J. D., Hagler, W. M. Jr., and Weinstock, D. (1995). Fusarium proliferatum culture material alters several production and immune performance parameters in white leghorn chickens. Immunopharmacol. Immunotoxicol. 17, 791-804. doi: 10.3109/08923979509037197

Qureshi, M. A., and Hagler, W. M. (1992). Effect of fumonisin-b1 exposure on chicken macrophage functions in vitro. Poult. Sci. 71, 104-112. doi: 10.3382/ ps.0710104

Richard, J. L. (1991). "Mycotoxins as immunomodulators in animal systems," in Mycotoxins, Cancer and Health, eds G. A. Bray and D. H. Ryan (Baton Rouge, LA: Pennington Center Nutrition Series, Louisiana State University Press).

Richardson, J. P., Mogavero, S., Moyes, D. L., Blagojevic, M., Krüger, T., Verma, A. H., et al. (2018a). Processing of Candida albicans Ecelp Is critical for Candidalysin maturation and fungal virulence. MBio 9, e02178-17. doi: 10. 1128/mBio.02178-17

Richardson, J. P., Willems, H. M. E., Moyes, D. L., Shoaie, S., Barker, K. S., Tan, S. L., et al. (2018b). candidalysin drives epithelial signaling, neutrophil recruitment, and immunopathology at the vaginal mucosa. Infect. Immun. 86, e00645-17. doi: 10.1128/IAI.00645-17

Richetti, A., Cavallaro, A., Ainis, T., and Fimiani, V. (2005). Effect of mycotoxins on some activities of isolated human neutrophils. Immunopharmacol. Immunotoxicol. 27, 433-446. doi: 10.1080/08923970500241071

Röhm, M., Grimm, M. J., D’Auria, A. C., Almyroudis, N. G., Segal, B. H., and Urban, C. F. (2014). NADPH oxidase promotes neutrophil extracellular trap formation in pulmonary aspergillosis. Infect. Immun. 82, 1766-1777. doi: 10 . 1128/IAI.00096-14

Rogiers, O., Frising, U. C., Kucharíková, S., Jabra-Rizk, M. A., van Loo, G., Dijck, P. Van, et al. (2019). Candidalysin crucially contributes to Nlrp3 inflammasome 
activation by Candida albicans Hyphae. MBio 10, e2221-e2218. doi: 10.1128/ mBio.02221-18

Romero, A., Ares, I., Ramos, E., Castellano, V., Martínez, M., Martínez-Larrañaga, M. R., et al. (2016). Mycotoxins modify the barrier function of caco-2 cells through differential gene expression of specific claudin isoforms: protective effect of illite mineral clay. Toxicology 353-354, 21-33. doi: 10.1016/j.tox.2016. 05.003

Saito, M., Tsuruta, O., Siriacha, P., Kawasugi, S., and Manabe, M. (1989). Atypical strains of Aspergillus flavus isolated in maize fields aflatoxin-producing ability and distribution in Thailand. JPN Int. Res. Center Agric. Sci. 23, 151-154.

Schlam, D., Canton, J., Carreño, M., Kopinski, H., Freeman, S. A., Grinstein, S., et al. (2016). Gliotoxin suppresses macrophage immune function by subverting phosphatidylinositol 3,4,5-trisphosphate homeostasis. MBio 7:e02242. doi: 10 . 1128/mBio.02242-15

Schroeder, H. W., and Boller, R. A. (1973). Aflatoxin production of species and strains of the Aspergillus flavus group isolated from field crops. Appl. Microbiol. 25, 885-889. doi: 10.1128/aem.25.6.885-889.1973

Seeboth, J., Solinhac, R., Oswald, I. P., and Guzylack-Piriou, L. (2012). The fungal T-2 toxin alters the activation of primary macrophages induced by TLR-agonists resulting in a decrease of the inflammatory response in the pig. Vet. Res. 43:35. doi: 10.1186/1297-9716-43-35

Shank, R. C., Bhamarapravati, N., Gordon, J. E., and Wogan, G. N. (1972). Dietary aflatoxins and human liver cancer. IV. Incidence of Primary Liver Cancer in Two Municipal Populations of Thailand. Food Cosmet. Toxicol. 10, 171-179. doi: 10.1016/S0015-6264(72)80195-0

Shirani, K., Zanjani, B. R., Mahmoudi, M., Jafarian, A. H., Hassani, F. V., Giesy, J. P., et al. (2018). Immunotoxicity of aflatoxin $\mathrm{M}_{1}$ : as a potent suppressor of innate and acquired immune systems in a subacute study. J. Sci. Food Vet. Agric. 98, 5884-5892. doi: 10.1002/jsfa.9240

Silvotti, L., Petterino, C., Bonomi, A., and Cabassi, E. (1997). Immunotoxicological effects on piglets of feeding sows diets containing aflatoxins. Vet. Record 141, 469-472. doi: 10.1136/vr.141.18.469

Smith, W. L., DeWitt, D. L., and Garavito, R. M. (2000). Cyclooxygenases: Structural. Cell. Mol. Biol. Ann. Rev. Biochem. Ann. Rev. Biochem. 69, 145-182. doi: 10.1146/annurev.biochem.69.1.145

Soliman, S. S. M., Baldin, C., Gu, Y., Singh, S., Gebremariam, T., Swidergall, M., et al. (2021). Mucoricin is a ricin-like toxin that is critical for the pathogenesis of mucormycosis. Nat. Microbiol. 6, 313-326. doi: 10.1038/s41564-02000837-0

Song, E., Xia, X., Su, C., Dong, W., Xian, Y., Wang, W., et al. (2014). Hepatotoxicity and genotoxicity of patulin in mice, and its modulation by green tea polyphenols administration. Food Chem. Toxicol. 71, 122-127. doi: 10.1016/j. fct.2014.06.009

Spikes, S., Xu, R., Nguyen, C. K., Chamilos, G., Kontoyiannis, D. P., Jacobson, R. H., et al. (2008). Gliotoxin production in Aspergillus fumigatus contributes to host-specific differences in virulence. J. Infect. Dis. 197, 479-486. doi: 10. $1086 / 525044$

Stanzani, M., Orciuolo, E., Lewis, R., Kontoyiannis, D. P., Martins, S. L. R., St John, L. S., et al. (2005). Aspergillus fumigatus suppresses the human cellular immune response via gliotoxin-mediated apoptosis of monocytes. Blood 105, 2258-2265. doi: 10.1182/blood-2004-09-3421

Su, J., Liu, D., Wang, Q., Lin, J., Song, S., and Huang, K. (2019). Long-time instead of short-time exposure in vitro and administration in vivo of ochratoxin a is consistent in immunosuppression. J. Agric. Food Chem. 67, 7485-7495. doi: 10.1021/acs.jafc.9b02595

Suen, Y. K., Fung, K. P., Lee, C. Y., and Kong, S. K. (2001). Gliotoxin induces apoptosis in cultured macrophages via production of reactive oxygen species and cytochrome $\mathrm{c}$ release without mitochondrial depolarization. Free Radical Res. 35, 1-10. doi: 10.1080/10715760100300541

Sugiyama, I., Muroi, M., Kinoshita, M., Hamada, O., Minai, Y., Sugita-Konishi, Y., et al. (2016). NF-KB activation via MyD88-dependent toll-like receptor signaling is inhibited by trichothecene mycotoxin deoxynivalenol. J. Toxicol. Sci. 41, 273-279. doi: 10.2131/jts.41.273

Sugui, J. A., Pardo, J., Chang, Y. C., Zarember, K. A., Nardone, G., Galvez, E. M., et al. (2007). Gliotoxin is a virulence factor of Aspergillus fumigatus: glip deletion attenuates virulence in mice immunosuppressed with hydrocortisone. Eukaryotic. Cell 6, 1562-1569. doi: 10.1128/EC.00141-07
Sun, M., Wang, S., Jiang, L., Bai, Y., Sun, X., Li, J., et al. (2018). Patulin induces autophagy-dependent apoptosis through lysosomal-mitochondrial axis and impaired mitophagy in HepG2 cells. J. Agric. Food Chem. 66, 12376-12384. doi: 10.1021/acs.jafc.8b03922

Surup, F., Medjedović, A., Szczygielski, M., Schroers, H. J., and Stadler, M. (2014). Production of trichothecenes by the apple sooty blotch fungus Microcyclospora tardicrescens. J. Agric. Food Chem. 62, 3525-3530. doi: 10.1021/jf500153d

Swidergall, M., Khalaji, M., Solis, N. V., Moyes, D. L., Drummond, R. A., Hube, B., et al. (2019). Candidalysin is required for neutrophil recruitment and virulence during systemic Candida albicans infection. J. Infect. Dis. 220, 1477-1488. doi: 10.1093/infdis/jiz322

Tatay, E., Espín, S., García-Fernández, A. J., and Ruiz, M. J. (2018). Estrogenic activity of zearalenone, $\alpha$-zearalenol and $\beta$-zearalenol assessed using the e-screen assay in MCF-7 cells. Toxicol. Mechanisms Methods 28, 239-242. doi: 10.1080/15376516.2017.1395501

Thurston, J. R., Richard, J. L., and Peden, W. M. (1986). "Immunomodulation in mycotoxicoses other than aflatoxicosis," in Diagnosis of Mycotoxicoses, eds J. L. Richard and J. R. Thurston (Dordrecht: Springer), 149-161. doi: 10.1007/97894-009-4235-6_14

Tsai, W. T., Lo, Y. C., Wu, M. S., Li, C. Y., Kuo, Y. P., Lai, Y. H., et al. (2016). Mycotoxin Patulin suppresses innate immune responses by mitochondrial dysfunction and P62/sequestosome-1-dependent mitophagy. J. Biol. Chem. 291, 19299-19311. doi: 10.1074/jbc.M115.686683

Tsunawaki, S., Yoshida, L. S., Nishida, S., Kobayashi, T., and Shimoyama, T. (2004). Fungal metabolite gliotoxin inhibits assembly of the human respiratory burst NADPH oxidase. Infect. Immun. 72, 3373-3382. doi: 10.1128/IAI.72.6.33733382.2004

Tuomi, T., Reijula, K., Johnsson, T., Hemminki, K., Hintikka, E. L., Lindroos, O., et al. (2000). Mycotoxins in crude building materials from water-damaged buildings. Appl. Environ. Microbiol. 66, 1899-1904. doi: 10.1128/AEM.66.5. 1899- 1904.2000

Ubagai, T., Tansho, S., Ito, T., and Ono, Y. (2008). Influences of aflatoxin b1 on reactive oxygen species generation and chemotaxis of human polymorphonuclear leukocytes. Toxicol. Vitro 22, 1115-1120. doi: 10.1016/j.tiv. 2008.01.007

Ukwuru, M. U., Ohaegbu, C. G., and Muritala, A. (2017). An overview of mycotoxin contamination of foods and feeds. J. Biochem. Microbial. 1:101.

van der Merwe, K. J., Steyn, P. S., Fourie, L., Scott, D. B., and Theron, J. J. (1965). Ochratoxin a, a toxic metabolite produced by aspergillus ochraceus wilh. Nature 205, 1112-1113. doi: 10.1038/2051112a0

Vane, J. R., Bakhle, Y. S., and Botting, R. M. (1998). Cyclooxygenases 1 and 2. Ann. Rev. Pharmacol. Toxicol. 38, 97-120. doi: 10.1146/annurev.pharmtox.38.1.97

Venkatasubbaiah, P., Sutton, T. B., and Chilton, W. S. (1995). The structure and biological properties of secondary metabolites produced by peltaster fructicola, a fungus associated with apple sooty blotch disease. Plant Dis. 79, 1157-1160.

Verma, A. H., Richardson, J. P., Zhou, C., Coleman, B. M., Moyes, D. L., Ho, J., et al. (2017). Oral epithelial cells orchestrate innate type 17 responses to candida albicans through the virulence factor candidalysin. Sci. Immunol. 2:eaam8834. doi: 10.1126 /sciimmunol.aam 8834

Videmann, B., Mazallon, M., Tep, J., and Lecoeur, S. (2008). Metabolism and transfer of the mycotoxin zearalenone in human intestinal Caco-2 cells. Food Chem. Toxicol. 46, 3279-3286. doi: 10.1016/j.fct.2008.07.011

Wan, D., Wang, X., Wu, Q., Lin, P., Pan, Y., Sattar, A., et al. (2015). Integrated transcriptional and proteomic analysis of growth hormone suppression mediated by trichothecene T-2 toxin in rat GH3 cells. Toxicol. Sci. 147, 326-338. doi: $10.1093 /$ toxsci/kfv131

Wan, L. Y., Turner, P. C., and El-Nezami, H. (2013). Individual and combined cytotoxic effects of fusarium toxins (Deoxynivalenol, Nivalenol, Zearalenone and Fumonisins B1) on swine jejunal epithelial cells. Food Chem. Toxicol. 57, 276-283. doi: 10.1016/j.fct.2013.03.034

Wang, H., Chen, Y., Zhai, N., Chen, X., Gan, F., Li, H., et al. (2017). Ochratoxin a-induced apoptosis of ipec-j2 cells through ros-mediated mitochondrial permeability transition pore opening pathway. J. Agric. Food Chem. 65, 1063010637. doi: 10.1021/acs.jafc.7b04434

Wang, J. S., Qian, G. S., Zarba, A., He, X., Zhu, Y. R., Zhang, B. C., et al. (1996). Temporal patterns of aflatoxin-albumin adducts in hepatitis b surface antigenpositive and antigen-negative residents of daxin, qidong county, people's republic of china. Cancer Epidemiol. Prevention Biomarkers 5, 253-261. 
Wang, N., Liang, H., and Zen, K. (2014). Molecular mechanisms that influence the macrophage M1-M2 polarization balance. Front. Immunol. 5:614. doi: 10.3389/ fimmu.2014.00614

Wang, X., Yu, H., Shan, A., Jin, Y., Fang, H., Zhao, Y., et al. (2018). Toxic effects of zearalenone on intestinal microflora and intestinal mucosal immunity in Mice. Food Agric. Immunol. 29, 1002-1011. doi: 10.1080/09540105.2018.15 03233

Ward, C., Chilvers, E. R., Lawson, M. F., Pryde, J. G., Fujihara, S., Farrow, S. N., et al. (1999). NF-KB activation is a critical regulator of human granulocyte apoptosis in vitro. J. Biol. Chem. 274, 4309-4318. doi: 10.1074/jbc.274.7.4309

Waring, P., Eichner, R. D., Mullbacher, A., and Sjaarda, A. (1988). Gliotoxin induces apoptosis in macrophages unrelated to its antiphagocytic properties. J. Biol. Chem. 263, 18493-18499.

Weindling, R. (1941). Experimental consideration of the mold-toxins of gliocladium and trichoderma. Phytopath 31, 991-1003.

Weindling, R., and Emerson, O. H. (1936). The Isolation of a toxic substance from the culture filtrate of trichoderma. Phytopathology 26, 1068-1070.

Wong, S., Schwartz, R. C., and Pestka, J. J. (2001). Superinduction of TNF- $\alpha$ and IL-6 in macrophages by vomitoxin (Deoxynivalenol) modulated by mRNA stabilization. Toxicology 161, 139-149. doi: 10.1016/S0300-483X(01)00331-6

Xiong, Z., Wang, Q., Xie, Y., Li, N., Yun, W., and Yang, L. (2021). Simultaneous detection of aflatoxin B1 and ochratoxin a in food samples by Dual DNA tweezers nanomachine. Food Chem. 338:128122. doi: 10.1016/j.foodchem.2020. 128122

Xu, Q., Shi, W., Lv, P., Meng, W., Mao, G., Gong, C., et al. (2020). Critical role of caveolin-1 in aflatoxin B1-induced hepatotoxicity via the regulation of oxidation and autophagy. Cell Death Dis. 11:6. doi: 10.1038/s41419-019-2197-6
Yang, G. H., Jarvis, B. B., Chung, Y. J., and Pestka, J. J. (2000). Apoptosis Induction by the satratoxins and other trichothecene mycotoxins: relationship to ERK, P38 MAPK, and SAPK/JNK activation. Toxicol. Appl. Pharmacol. 164, 149-160. doi: 10.1006/taap.1999.8888

Zhang, C., Chen, F., Liu, X., Han, X., Hu, Y., Su, X., et al. (2019). Gliotoxin induces cofilin phosphorylation to promote actin cytoskeleton dynamics and internalization of aspergillus fumigatus into type II human pneumocyte cells. Front. Microbiol. 10:1345. doi: 10.3389/fmicb.2019.01345

Zhou, H. R., Islam, Z., and Pestka, J. J. (2003). Rapid, sequential activation of mitogen-activated protein kinases and transcription factors precedes proinflammatory cytokine mRNA expression in spleens of mice exposed to the trichothecene vomitoxin. Toxicol. Sci. 72, 130-142. doi: 10.1093/toxsci/kfg006

Zhou, H. R., Yan, D., and Pestka, J. J. (1997). Differential cytokine mrna expression in mice after oval exposure to the trichothecene vomitoxin (Deoxynivalenol): dose response and time course. Toxicol. Appl. Pharmacol. 144, 294-305. doi: 10.1006/taap.1997.8132

Conflict of Interest: The authors declare that the research was conducted in the absence of any commercial or financial relationships that could be construed as a potential conflict of interest.

Copyright (C) 2021 Brown, Priest, Naglik and Richardson. This is an open-access article distributed under the terms of the Creative Commons Attribution License (CC BY). The use, distribution or reproduction in other forums is permitted, provided the original author(s) and the copyright owner(s) are credited and that the original publication in this journal is cited, in accordance with accepted academic practice. No use, distribution or reproduction is permitted which does not comply with these terms. 